\title{
Flora of Espírito Santo, Brazil \\ Myrcia (Myrtaceae) in the Vale Natural Reserve, Linhares, Espírito Santo, Brazil
}

\author{
Fernanda Savioli Scaravelli ${ }^{1,4}$, Paulo Henrique Gaem ${ }^{2,5,8}$, Karinne Sampaio Valdemarin ${ }^{2,6}$, Eve Lucas ${ }^{3}$ \\ \& Fiorella Fernanda Mazine ${ }^{1,7}$
}

\begin{abstract}
Myrcia (Myrteae, Myrtaceae) is represented by 101 species in the Brazilian state of Espírito Santo, but local floristic surveys on this genus still lack in this centre of diversity and endemism. In this context, a taxonomic account of Myrcia in the Vale Natural Reserve (VNR), Linhares, Espírito Santo, is presented. Forty-six species were registered in this study, representing $46 \%$ of the richness of the genus in Espírito Santo. Twenty-five species (54\%) are endemic to the Atlantic domain and seven are endemic to Espírito Santo. Myrcia scytophylla is reported in the Atlantic forest for the first time and M. cymatophylla, M. congestiflora, and $M$. ferruginosa are new occurrences in the state. Species composition revealed by this study considerably differs from that of a previous checklist. Representatives of Myrcia can be found in all main vegetation types of the VNR and the anthropic areas. The study site must be considered prioritary for conservation of Myrcia due to the presence of a rich assemblage, which also includes restrict and threatened species.
\end{abstract}

Key words: Atlantic forest, floristic survey, Myrciinae, tabuleiro forest.

\section{Resumo}

Myrcia (Myrteae, Myrtaceae) é representada por 101 espécies no estado brasileiro do Espírito Santo, contudo, estudos florísticos com este gênero ainda são escassos neste centro de diversidade e endemismo. Neste contexto, um estudo taxonômico de Myrcia na Reserva Natural Vale (RNV), Linhares, Espírito Santo, é aqui apresentado. Quarenta e seis espécies foram registradas neste estudo, compreendendo $46 \%$ da riqueza do gênero no Espírito Santo. Vinte e cinco espécies (54\%) são endêmicas do domínio atlântico e sete são endêmicas do Espírito Santo. Myrcia scytophylla é registrada na floresta atlântica pela primeira vez e $M$. cymatophylla, $M$. congestiflora e $M$. ferruginosa são novas ocorrências para o estado. A composição de espécie revelada por este estudo difere consideravelmente da publicada por uma listagem anterior. Os representantes de Myrcia podem ser encontrados em todas as principais formações vegetais da RNV e em áreas antrópicas. Este sítio deve ser considerado como prioritário para a conservação de táxons pertencentes a Myrcia devido à presença de uma assembleia rica, incluindo espécies restritas e ameaçadas de extinção.

Palavras-chave: Floresta atlântica, levantamento florístico, Myrciinae, floresta de tabuleiro.

\footnotetext{
${ }^{1}$ Universidade Federal de São Carlos, Campus Sorocaba, Centro de Ciências e Tecnologias para a Sustentabilidade, Sorocaba, SP, Brazil.

${ }^{2}$ Universidade Estadual de Campinas, Inst. Biologia, Campinas, SP, Brazil.

${ }^{3}$ Royal Botanic Gardens, Kew, Richmond, Surrey, United Kingdom. ORCID: <https://orcid.org/0000-0002-7603-435X>.

${ }^{4}$ ORCID: $<$ https://orcid.org/0000-0002-4386-4445>. ${ }^{5}$ ORCID: $<$ https://orcid.org/0000-0003-3054-7325>.

${ }^{6}$ ORCID: <https://orcid.org/0000-0002-9564-1163>. ${ }^{7}$ ORCID: <https://orcid.org/0000-0002-2604-6088>.

${ }^{8}$ Author for correspondence: phgaem@gmail.com
} 


\section{Introduction}

The plant family Myrtaceae comprises ca. 5,800 species and is characterised by internal phloem, vestured pits on the xylem vessels, leaves with entire margins containing oil glands, and flowers with numerous stamens and a usually inferior ovary (Wilson et al. 2001). All Brazilian taxa belong to Myrteae, a tribe recognisable by indehiscent fleshy fruits, unicellular or multicellular hairs, and transeptal vascular system (Schmid 1972; Wilson et al. 2001). Within Myrteae, Lucas et al. (2019) included a broadly-defined Myrcia as the only genus in subtribe Myrciinae. This genus is characterised by usually well-developed inflorescences, 2-3-locular ovaries with two ovules per locule, seed coats soft, and embryos with folded, leafy cotyledons and a well-developed hypocotyl (Lucas et al. 2011). Species have been divided among nine sections (Lucas et al. 2018), however, ongoing recent research has demonstrated that anther and calyx features are more variable than recorded to date, and sectional delimitations will need adjustment; some diagnostic updates to sectional circumscriptions are presented here. This widespread taxon is distributed from Mexico and the Caribbean to Argentina, in the Americas, with the highest diversity in the Brazilian Atlantic forest, in particular at higher elevation, where the genus is suggested to have originated (Oliveira-Filho \& Fontes 2000; Santos et al. 2017).

Myrcia is represented by 101 species in the state of Espírito Santo, of which 18 are endemic (Santos et al. 2020). Studies have revealed high diversity of Myrtaceae in the state (Barroso \& Peixoto 1995; Mazine \& Souza 2007, 2009; Sobral 2007; Giaretta \& Peixoto 2015; Giaretta et al. 2015; Luber et al. 2017; Tuler et al. 2017; Valdemarin et al. 2019a, b, 2020a, b), but floristic surveys in Myrcia still lack. In this context, a taxonomic survey of Myrcia in the Vale Natural Reserve (VNR), in the municipality of Linhares, is here presented.

\section{Material and Methods}

The VNR is located in the North of the state of Espírito Santo, covering 23,000 hectares (Fig. 1) (Jesus \& Rolim 2005; Peixoto \& Jesus 2016). It is part of a mosaic of protected areas known by high biological diversity and endemism (Peixoto \& Silva 1997). Myrtaceae is the second most species-rich family of plants in VNR, with Myrcia being the third most representative genus in the local flora (Rolim et al. 2016a). The study site lies within the tabuleiro coastal forests, with altitudes varying from 28 to 65 metres above sea level (Jesus et al. 1992). The climate has a wet season in the summer (from December to February) and a dry season in the winter (from May to September) (Engel \& Martins 2005), the average annual precipitation is $1,227 \mathrm{~mm}$, and average temperature is $23.3{ }^{\circ} \mathrm{C}$ (Rolim et al. 2016b).

Besides anthropic areas and riverine vegetation, there are four main vegetation types in the VNR: the mata alta forest, occurring in deep clayish soils where trees can grow up to $35 \mathrm{~m}$ tall; the mussununga forest, found in sandy soils where the canopy reaches up to $10 \mathrm{~m}$; the campo nativo formation, composed by herbs and shrubs and also growing in sandy soils; and the permanently or periodically flooded areas, containing a lower stratum composed of herbs and shrubs and an upper stratum of trees up to $12 \mathrm{~m}$ tall (Araújo et al. 2008; Jesus \& Rolim 2005; Peixoto et al. 2008; Simonelli et al. 2008).

Collections of the herbaria CVRD, ESA, RB, RBR, SORO, SP, SPSF were visited and high-resolution images of specimens deposited at CEPEC, K, MBM, SPF, UEC, and VIES were

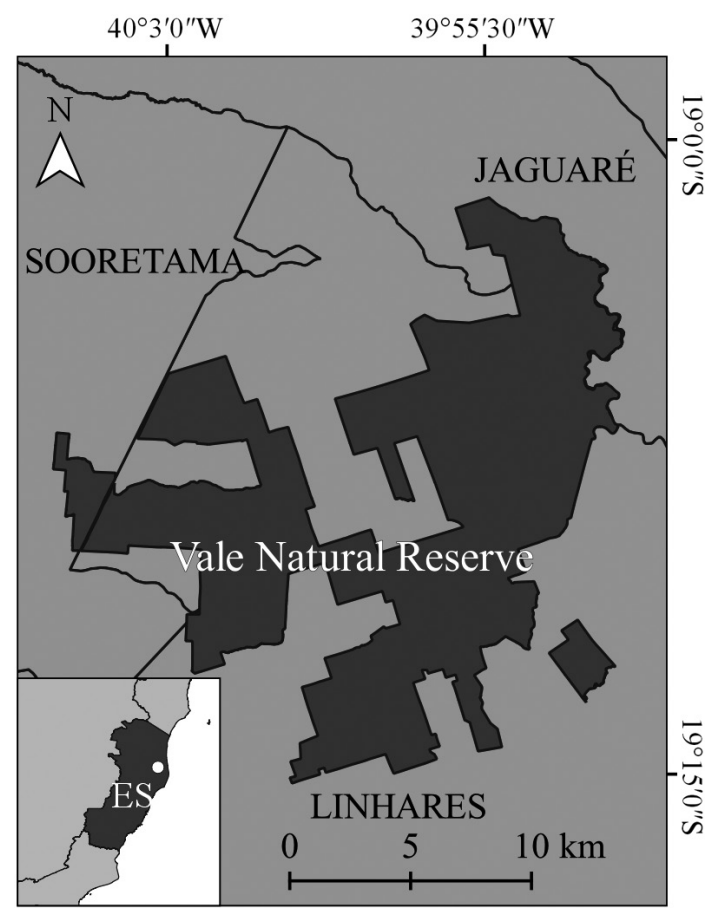

Figure 1 - Location of the Vale Natural Reserve in Espírito Santo state, southeastern Brazil. 
viewed online (acronyms according to Thiers, continuously updated). Samples were also collected during field work between December 2015 and January 2017. Species were delimited based on morphological differences in a local scale, and specimens were assigned to species by comparison with exsiccatae named by Myrtaceae specialists and images of type specimens available online. The taxa treated here are congruent with species concepts over the range of the genus in most cases, however, in some cases distinct local forms that could be included in highly variable widespread species are retained here as independent entities (Myrcia sp.1-3); the affinities of the species and their taxonomic positions are justified in each case. Synonyms of the accepted species names are listed if they were formerly broadly applied and are still likely to be found in herbarium specimens collected in the study site. Taxonomic descriptions and identification keys were produced based on dried material, and morphological terminology follows recent works in Myrcia (e.g., Lucas et al. 2011, 2016, 2018; Santos et al. 2016; Vasconcelos et al. 2017). Materials from the study site are cited as "examined specimens" and individuals from other localities are referred to as "additional specimens". Abbreviations of the Brazilian states follow IBGE (2020).

\section{Results}

Myrcia is represented by 46 species in the VNR, comprising $46 \%$ of the richness of the genus in Espírito Santo state and 12\% in Brazil (Santos et al. 2020). Five taxa were identified in genus level and 41 taxa were identified at the species level. Species belonging to all the currently accepted sections of Myrcia were found in the study site, except $M$. sect. Tomentosae E.Lucas \& D.F.Lima. Myrcia sect. Aulomyrcia (O.Berg) Griseb. is the most speciose section of the genus at the study site (16 spp.), followed by $M$. sect. Gomidesia (O.Berg) B.S.Amorim \& E.Lucas (8 spp.), M. sect. Calyptranthes (Sw.) A.R.Lourenço \& E.Lucas (6 spp.), M. sect. Myrcia (5 spp.), $M$. sect. Aguava (Raf.) D.F.Lima \& E.Lucas and $M$. sect. Eugeniopsis (O.Berg) M.F.Santos \& E.Lucas (3 spp. each), and M. sect. Reticulosae D.F.Lima \& E.Lucas and $M$. sect. Sympodiomyrcia M.F.Santos \& E.Lucas (2 spp. each). One species could not be assigned to any infra-generic category of the genus.

Of the total, 25 species (54\%) are endemic to the Atlantic domain and seven are endemic to Espírito Santo state. Myrcia scytophylla (Diels) E.Lucas \& C.E.Wilson, a species hitherto known only from Amazonian specimens, is reported in the Atlantic domain for the first time. Myrcia cymatophylla E.Lucas \& G.P.Burton and $M$. congestiflora Caliari \& V.C.Souza are new occurrences in Espírito Santo state and the occurrence of $M$. ferruginosa Mazine, a species previously assigned as "doubtful" in the state (Santos et al. 2020), is confirmed. Myrcia sucrei (G.M.Barroso \& Peixoto) E.Lucas \& C.E.Wilson and $M$. plusiantha Kiaersk. are assessed by CNCFlora (2020) as Near Threatened of extinction and three other species are currently under some degree of threat: Myrcia isaiana G.M.Barroso \& Peixoto (Endangered), M. gilsoniana G.M.Barroso $\&$ Peixoto (Critically Endangered), and $M$. riodocensis G.M.Barroso \& Peixoto (Critically Endangered).

Species of Myrcia occur in all main vegetation types of the VNR. The mata alta forests are the richest areas in species of the genus in the study site, with 39 species (18 of them endemic). Fifteen, eight, and five species were recorded in the mussununga forest, the campo nativo, and flooded areas, respectively; the two former have no endemic species, whilst the only taxon exclusive to the flooded vegetation is Myrcia neolucida A.R.Lourenço \& E.Lucas. Eleven species occur in riparian vegetation and five species extends into anthropic areas (Tab. S1, available on supplementary material < https://doi.org/10.6084/ m9.figshare.17161151.v1>).

Myrcia DC., Dict. Class. Hist. Nat. 11: 401. 1827.

Figs. 2-9

Shrubs or trees. Branching of stems monopodial (with a dominant axis) or sympodial (dichotomous). Trichomes simple or dibrachiate. Leaves opposite, rarely alternate or verticillate. Inflorescences usually well-developed, monopodial (main axis well-developed) or sympodial (main axis reduced and secondary branches congested), higher-order branches bearing triads or dichasia or sometimes reduced and spike-like. Flowers 4-5-merous; calyx various; corolla well-developed or vestigial; hypanthium prolonged above the summit of the ovary or not; floral disc glabrous or pubescent; ovary 2-3(-5)-locular, with 2 ovules per locule, placentation axillary. Fruits ellipsoid, fusiform, globose, or obloid; seed testa thin and papery, embryo with foliaceous and folded cotyledons and a well-developed hypocotyl. 


\section{Key to sections of Myrcia in the VNR}

1. Hypanthium not or only slightly longitudinally extended above the summit of the ovary, floral disc, inner surface of hypanthium, and staminal ring pubescent (Figs. 6e; 8c) .....

1'. Hypanthium conspicuously extended longitudinally above the summit of the ovary, floral disc, inner surface of hypanthium, and staminal ring glabrous (e.g., Fig. 8f) (pubescent in Myrcia lacerdeana)..... 3

2. Hypanthium slightly extended longitudinally above the summit of the ovary, staminal ring thin, anthers with asymmetrical thecae, maintaining curvature at dehiscence (Fig. 6e-f) .....

5. Myrcia sect. Gomidesia

2'. Hypanthium unextended above the summit of the ovary, staminal ring thick, anthers with symmetrical thecae, reversing curvature at dehiscence (Fig. 8c-d). .. 6. Myrcia sect. Myrcia

3. Leaf blades strongly discolourous (Fig. 9d), abaxial surface visibly contrasting with dark dots; calyx basally fused in flower bud, lobes distinguishable before anthesis (Fig. 9b) ....... 4. Myrcia sect. Eugeniopsis

3'. Leaf blades not strongly discolourous (e.g., Fig. 9e), abaxial surface not visibly contrasting with dark dots; calyx various. If glands contrasting with blade surface, then calyx completely fused in bud and lobes indistinguishable before anthesis (e.g., Fig. 2e).

4. Leaf blades with inter-secondary and tertiary veins raised, conspicuously reticulate; staminal ring thick and pubescent (exceptionally glabrous in Myrcia maximiliana); ovary 3-locular (e.g., Fig. 2d); fruits ellipsoid (e.g., Fig. 8e).........7. Myrcia sect. Reticulosae

4'. Leaf blades with inter-secondary and tertiary veins flat, inconspicuously reticulate; staminal ring thin and glabrous; ovary 2-locular (3-locular in Myrcia sect. Aguava); fruits globose (e.g., Fig. 6d).

5. Vegetative branching sympodial (Fig. 7a); calyx completely fused in flower bud, opening as a calyptra (i.e., completely tearing transversely as a unit) at anthesis (Fig. 6c). 3. Myrcia sect. Calyptranthes

5'. Vegetative branching monopodial (e.g., Fig. 3a) or sympodial; calyx open (e.g., Fig. 2c) or partly to completely fused in flower bud, opening in intact (Fig. 4d) or torn lobes (e.g., Fig. 2f) at anthesis .....

6. Vegetative branching sympodial (Fig. 8b); inflorescences with regular (i.e., opposite) branching (Fig. 8b); calyx free in flower bud, opening in partly torn lobes transversely (Fig. 9c) ..... 8. Myrcia sect. Sympodiomyrcia

6'. Vegetative branching monopodial or rarely sympodial; inflorescences with irregular (i.e., alternate to opposite) branching (e.g., Fig. 4a); calyx various, opening in free lobes (Fig. 4c) or these torn longitudinally (e.g., Fig. 9a)...... 7

7. Calyx free in flower bud, opening in 5 intact lobes, ovary 3-locular (Fig. $2 \mathrm{~d}$ ); fruit crowned by the hypanthial tube and the calyx. 1. Myrcia sect. Aguava

7'. Calyx free or partly to completely fused in flower bud, opening in 4-5 intact or longitudinally torn lobes, ovary 2-locular; calyx lobes and hypanthial tube persistent or deciduous in fruit

2. Myrcia sect. Aulomyrcia

\section{Myrcia sect. Aguava (Raf.) D.F.Lima \& E.Lucas,} Kew Bull. 73(9): 7. 2018.

Vegetative branching monopodial. Leaves with inter-secondary and tertiary veins flat; blade not strongly discolourous, abaxial surface not visibly contrasting with dark dots. Inflorescences with alternate, opposite, or sub-opposite branching. Flower buds obovoid or turbinate; calyx free in bud, opening in 5 intact lobes; hypanthium longitudinally prolonged above the summit of the ovary, glabrous on the inner surface; flower disc glabrous, staminal ring glabrous, comprising up to $40 \%$ of the total disc width; anthers with symmetrical thecae, reversing curvature at dehiscence; ovary 3-locular, with two ovules per locule. Fruits globose, crowned by the hypanthial tube and the calyx. 
Three species of Myrcia sect. Aguava occur in the VNR, a group represented by 32 species throughout the distribution of genus (Lucas et al. 2011; Lima et al. 2021). This section is recognised in the study site by the combination of leaves with inconspicuous reticulation and flowers with thin staminal ring and 3-locular ovaries. The number of locules in ovaries is shared with Myrcia sect.
Reticulosae, but species of the latter section have leaves with conspicuous reticulation, flowers with thick staminal ring, and ellipsoid fruits ( $v s$. globose in M. sect. Aguava). Myrcia sect. Aguava may also be confused with $M$. sect. Aulomyrcia, a section characterised by 2-locular ovaries and variable levels of calyx fusion in flower bud (vs. always free in M. sect. Aguava in the study site).

\section{Key to species of Myrcia sect. Aguava in the VNR}

1. Leaf blades discolourous, midvein flat to slightly sulcate adaxially, marginal veins two

1'. Leaf blades concolourous, midvein raised adaxially, marginal vein single. 1.1. Myrcia gilsoniana

2. Inflorescences with regular (i.e., opposite) branching, rachis glabrous or with sparse indumentum; flower buds glabrous, calyx lobes ca. $0.05 \mathrm{~cm}$. 1.2. Myrcia laxiflora

2'. Inflorescences with irregular (i.e., alternate to opposite) branching, rachis with dense indumentum; flower buds with dense indumentum; calyx lobes $0.1-0.2 \mathrm{~cm}$. 1.3. Myrcia rufipes

\subsection{Myrcia gilsoniana G.M.Barroso \& Peixoto,} Acta Bot. Bras. 4(2): 7. $1990 . \quad$ Fig. 4c

Trees 1.5-12 m. Leaves with petiole $0.5-1$ $\mathrm{cm}$ long; blade discolourous, elliptic, oblong, or obovate, $4.5-16.5 \times 1.5-6 \mathrm{~cm}$, chartaceous, glabrous or with light brown, sparsely distributed trichomes concentrated along the midvein adaxially and distributed along the whole blade abaxially; apex acute to short-acuminate, base cuneate to obtuse or occasionally rounded; midvein flat to slightly sulcate adaxially and raised abaxially, secondary veins $12-16$ pairs, usually raised on both surfaces, marginal veins two, the inner $0.15-0.25 \mathrm{~cm}$ from the margin. Inflorescences $2.5-10 \mathrm{~cm}$ long, axillary or terminal; indumentum on the rachis light brown, sparse to dense; branching alternate or subopposite; bracts not seen, bracteoles lanceolate, ca. $0.15 \mathrm{~cm}$ long. Flower buds turbinate, $0.3-0.4$ $\mathrm{cm}$ long, glabrous; calyx open, with 5 free lobes, these obtuse or rounded, ca. $0.1 \mathrm{~cm}$ long. Fruits globose, $0.5-0.8 \mathrm{~cm}$ diam., not pruinose, not costate, glabrous, crowned by the hypanthium tube and the calyx.

Examined material: mata alta, aceiro Calimã, 20.XI.2012, D.A. Folli 6945 (CVRD); estrada do viveiro, 17.II.2014, L. Biral 941 (CVRD); estrada Jueirana.Vermelha, 6.XII.2011, G.S. Siqueira 685 (CVRD); 22.II.2013, G.S. Siqueira 861 (CVRD, RB); Mussununga, aceiro Calimã, 17.III.1997, D.A. Folli 2966 (CVRD); 14.XI.2003, G.S. Siqueira 64 (CVRD); 14.XII.2004, D.A. Folli 5012 (CVRD); 10.XI.2005, D.A. Folli 5119 (CVRD); área antrópica, próximo à casa do guarda no Rio Barra Seca, 8.XI.1972, J. Spada 57 (CVRD, RB).

Myrcia gilsoniana is known from the BA and ES states, in the Atlantic domain (Santos et al. 2020). Within the VNR it was registered in anthropic areas and the mata alta and mussununga forests. Flowers were collected in November and December and fruits were collected in February and March. Remarkable features of this species are thick midveins of its leaves, turbinate flower buds, and evidently glandulose calyx lobes.

1.2. Myrcia laxiflora Cambess., Fl. Bras. Merid. 2: 319.1832.

Fig. 2a-c

Shrubs or treelets up to $2 \mathrm{~m}$. Leaves with petiole $0.5-0.8 \mathrm{~cm}$ long; blade concolourous, elliptic, $6.5-12.5 \times 2.5-5.2 \mathrm{~cm}$, slightly coriaceous, glabrous on both surfaces or with sparsely distributed yellowish-brown indumentum along the midvein abaxially; apex acuminate, base obtuse to rounded; midvein raised on both surfaces, secondary veins $12-18$ pairs, raised on both surfaces, marginal vein $0.1-0.2 \mathrm{~cm}$ from the margin. Inflorescences 2.5-9 cm long, axillary or terminal, glabrous or with yellowish-brown sparsely distributed indumentum on the rachis; branching opposite; bracts lanceolate, $0.2-0.5 \mathrm{~cm}$ long, bracteoles narrowly lanceolate, ca. $0.1 \mathrm{~cm}$ long. Flower buds obovoid, ca. $0.3 \mathrm{~cm}$ long, glabrous; calyx open, with 5 free lobes, these rounded, ca. 0.05 


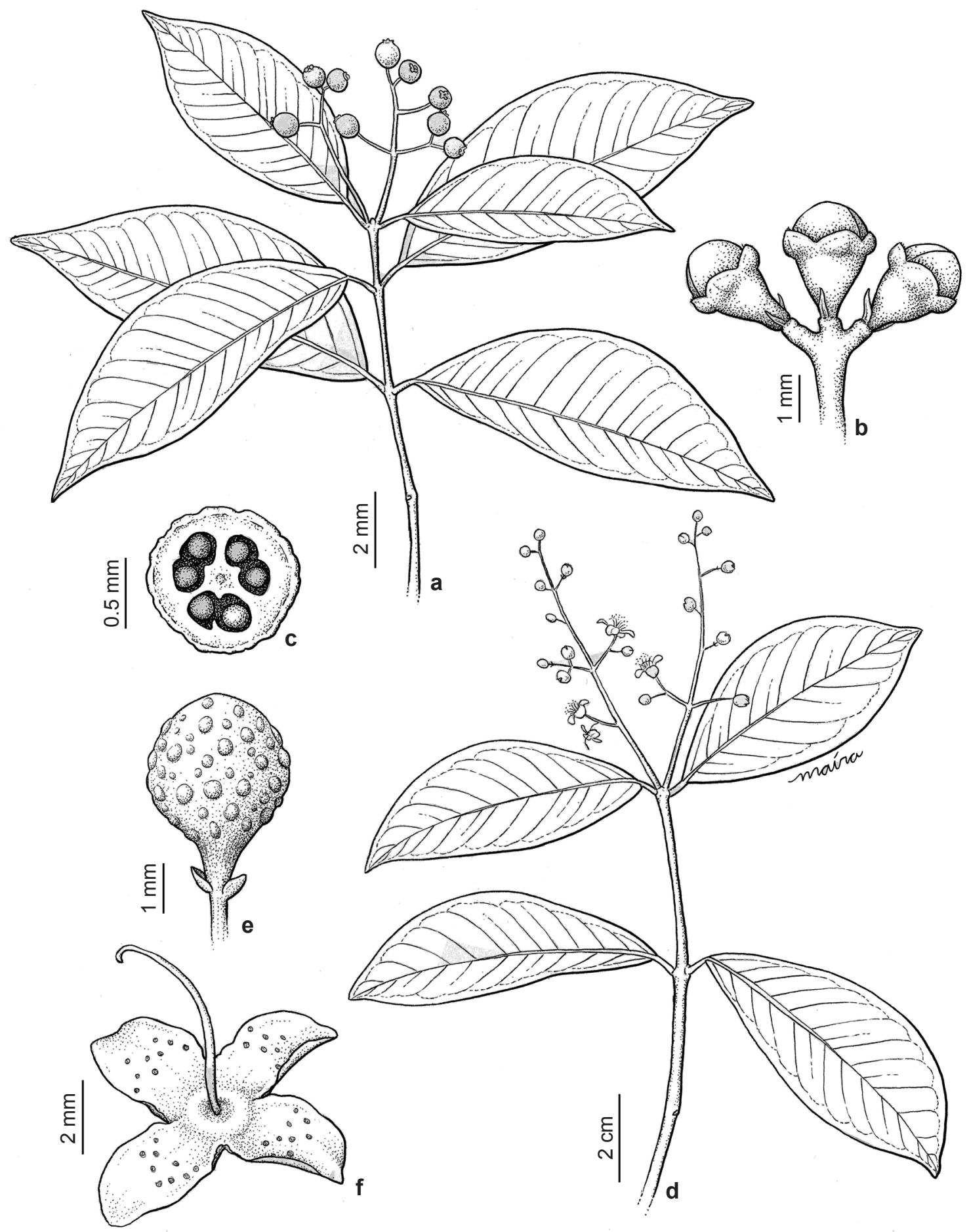

Figure 2 - a-c. Myrcia laxiflora - a. branch; b. flower buds; c. cross section of ovary. d-f. M. neoestrellensis - d. branch; e. flower bud; f. old flower. 
cm long. Fruits globose, ca. $0.6 \mathrm{~cm}$ diam., not pruinose, not costate, glabrous, crowned by the hypanthium tube and calyx.

Examined material: mata alta, aceiro Arlindinho, 28.I.2015, D.A. Folli 7327 (CVRD, SORO); aceiro Milanês, 11.II.2000, D.A. Folli 3572 (CVRD); mata ciliar, aceiro do viveiro, 23.XI.2001, D.A. Folli 4125 (CVRD, SORO); estrada da Gávea, 14.XI.2005, D.A. Folli 5130 (CVRD).

Myrcia laxiflora occurs in PE state and all states of southeastern Brazil, in tropical forests (Santos et al. 2020). It was registered in the VNR in the mata alta forests and riparian vegetation, where flowering material was collected in November and fruiting material was collected in February. It is similar to Myrcia rufipes, being distinguished mainly by glabrous flower buds and leaves and smaller calyx lobes.

\subsection{Myrcia rufipes DC., Prodr. 3: 247. 1828.}

Shrubs or trees up to $5 \mathrm{~m}$. Leaves with petiole 0.5-1.3 cm long; blade concolourous, narrowly elliptic, 4-11.5 × 1.5-3.5 cm, chartaceous, indumentum yellowish-brown on both surfaces; apex acute to acuminate, base cuneate; midvein raised on both surfaces, secondary veins 14-18 pairs, raised on both surfaces, marginal vein ca. $0.1 \mathrm{~cm}$ from the margin. Inflorescences 3.5-7.5 $\mathrm{cm}$ long, axillary or terminal, with yellowishbrown indumentum on the rachis, dense; branching alternate or sub-opposite; bracts not seen, bracteoles not seen. Flower buds obovoid, ca. $0.3 \mathrm{~cm}$ long, indumentum yellowish-brown, dense; calyx open, with 5 free lobes, these obtuse, $0.1-0.2 \mathrm{~cm}$ long. Fruits globose, $0.3-0.5$ cm diam., not pruinose, not costate, with sparse indumentum, crowned by the hypanthium tube and calyx.

Examined material: mata alta, estrada do Flamengo, 9.II.1999, E. Nic Lughadha 177 (CVRD, RB, SP).

Additional material: BRAZIL. ALAGOAS: Pilar, floresta sobre solo arenoso, BR-101, entre Messias e São Miguel dos Campos, 28.VII.2001, V.C. Souza et al. 26674 (ESA).

Myrcia rufipes is distributed from AL, BA and MT to SP states, occurring in the Caatinga, Cerrado, and Atlantic domains (Santos et al. 2020). In VNR it occurs in the mata alta forests, where flowers were collected in February and fruits were collected in June. It resembles Myrcia laxiflora, but differs mainly in denser indumentum and longer calyx lobes.
2. Myrcia sect. Aulomyrcia (O.Berg) Griseb., Fl. Brit. W. I. 234. 1864.

Vegetative branching monopodial or less often sympodial. Leaves with inter-secondary and tertiary veins usually flat; blade usually not strongly discolourous, abaxial surface usually not visibly contrasting with dark dots. Inflorescences with alternate, opposite, or sub-opposite branching. Flower buds globose, obovoid, or turbinate; calyx free or partly to completely fused in bud, opening in 4-5 intact or partly to completely torn lobes longitudinally; hypanthium longitudinally prolonged above the summit of the ovary, glabrous on the inner surface; flower disc glabrous, staminal ring comprising up to $40 \%$ of the total disc width; anthers with symmetrical thecae, reversing curvature at dehiscence; ovary 2-locular, with two ovules per locule. Fruits globose, calyx lobes and hypanthial tube persistent or deciduous.

Myrcia sect. Aulomyrcia has 140 recognised species distributed mainly in the Atlantic and Amazonian forests (Lucas et al. 2018). A morphologically diverse set of 16 species of this section occurs in the VNR, all of them with flowers with glabrous discs, thin staminal rings, extended hypanthia, and 2-locular ovaries. When comparing species of Myrcia sect. Aulomyrcia with free calyx lobes to any species of $M$. sect. Aguava in the study site, the single diagnostic character is ovary locularity (3-locular in M. sect. Aguava). The floral characters of Myrcia sect. Aulomyrcia also occur in the 2-locular M. sect. Eugeniopsis and M. sect. Sympodiomyrcia, but the former has strongly discolourous leaves with conspicuously dark-punctate abaxial surface, while the latter has sympodial vegetative branching and calyx lobes partly tearing transversely (sometimes detaching completely from hypanthium) at anthesis, features not usually found in $M$. sect. Aulomyrcia in the study site. A particular case of Myrcia sect. Aulomyrcia in the VNR is Myrcia neoestrellensis, a species with sympodial branching and darkdotted leaves, but completely closed calyces, a feature not observed in M. sect. Eugeniopsis and M. sect. Sympodiomyrcia. Besides Myrcia sect. Aulomyrcia, completely closed calyces are also present in species of $M$. sect. Calyptranthes of the study site, in which it detaches completely as a calyptra at anthesis (vs. tearing in lobes in $M$. sect. Aulomyrcia). 


\section{Key to species of Myrcia sect. Aulomyrcia in the VNR}

1. Calyx completely closed in flower bud, lobes indistinguishable before anthesis and completely torn in open flowers and fruits.

1'. Calyx free or partly fused in flower bud, lobes distinguishable before anthesis, intact or torn only at the base in open flowers and fruits

2. Petioles $1-1.2 \mathrm{~cm}$; leaf blades $6.5-13 \mathrm{~cm}$ wide, midvein raised adaxially, lateral veins $20-35$ pairs; inflorescence rachis bearing ferruginous indumentum; flower buds $0.5-0.7 \mathrm{~cm}$

2.16. Myrcia sucrei

2'. Petioles $0.3-1 \mathrm{~cm}$; leaf blades $1-6.3 \mathrm{~cm}$ wide, midvein flat to sulcate adaxially, lateral veins $8-18$ pairs; inflorencence rachis glabrous or bearing brown to yellow indumentum; flower buds $0.15-0.4$ $\mathrm{cm}$.

3. Leaf blades slightly discolourous, lateral veins inconspicuous abaxially, marginal vein single; inflorescences 1.4-2.1 cm, branching regular (i.e., opposite)..... 2.9. Myrcia neosuaveolens

3'. Leaf blades discolourous, lateral veins raised abaxially, marginal veins two; inflorescences 2-10.5 cm, branching irregular (i.e., alternate to opposite). If lateral veins inconspicuous, then inflorescences at least $5 \mathrm{~cm}$......

4. Secondary veins inconspicuous abaxially; flower bud with conic apex

2.4. Myrcia excoriata

4'. Secondary veins raised abaxially; flower bud with rounded apex

5. Bracteoles persistent at anthesis (seen in collections with mature inflorescences); flower buds obovoid, with yellowish-brown indumentum.

2.10. Myrcia neuwiediana

5'. Bracteoles deciduous at anthesis (scars seen in collections with mature inflorescences); flower buds globose, glabrous.

6. Leaf blades $6-8.5 \mathrm{~cm}$ wide, slightly coriaceous, secondary veins $8-10$ pairs, raised adaxially; inflorescence rachis glabrous; bracteoles ca. $0.1 \mathrm{~cm}$

2.7. Myrcia neoestrellensis

6'. Leaf blades $8-10.5 \mathrm{~cm}$ wide, chartaceous, secondary veins $12-18$ pairs, inconspicuous adaxially; inflorescence rachis with sparse indumentum; bracteoles $0.15-0.2 \mathrm{~cm}$.

2.8. Myrcia neoregeliana

7. Leaf blades with midvein adaxially raised...

7'. Leaf blades with midvein adaxially flat or sulcate

8. Calyx lobes acute.

2.12. Myrcia racemosa

8'. Calyx lobes obtuse or rounded

9. Trees 20-28 m; leaf blades coriaceous, base obtuse, rounded, or cordate; inflorescence rachis glabrous, bracteoles ca. 0.15 $\mathrm{cm}$; calyx partly closed, tearing in 4 regular lobes at anthesis

2.3. Myrcia excelsa

9'. Shrubs to trees 2-18 m; leaf blades chartaceous, base cuneate or obtuse; inflorescence rachis densely covered with trichomes, bracteoles $0.25-0.7 \mathrm{~cm}$; calyx various. If rachis with sparse indumentum and bracteoles shorter than $0.25 \mathrm{~cm}$, then calyx open in bud, with 5 free lobes at anthesis.

10. Flower buds obovoid, ca. $0.6 \mathrm{~cm}$, calyx partly closed in bud, tearing in 4-5 lobes at anthesis.

2.11. Myrcia obversa

10 '. Flower buds globose or turbinate, $0.2-0.3 \mathrm{~cm}$, calyx open in bud, with 5 intact lobes at anthesis. 
11. Shrubs or trees $2-3 \mathrm{~m}$; leaf blades $8-32 \times 2-8 \mathrm{~cm}$, secondary veins $12-30$ pairs, inner marginal vein $0.2-0.8 \mathrm{~cm}$ from margin; inflorescence rachis with dense indumentum, bracts $0.5-0.8 \mathrm{~cm}$, bracteoles ca. $0.25 \mathrm{~cm}$; flower buds globose.

2.2. Myrcia eumecephylla

11'. Trees $12-18 \mathrm{~m}$; leaf blades $3.5-9.5 \times 1.6-3.5 \mathrm{~cm}$, secondary veins $12-14$ pairs, inner marginal vein $0.15-0.25 \mathrm{~cm}$ from margin; inflorescence rachis with sparse indumentum, bracts ca. $0.2 \mathrm{~cm}$, bracteoles $0.05-0.1 \mathrm{~cm}$; flower buds turbinate. 2.14. Myrcia scytophylla

12. Calyx 4-merous; fruits not costate 2.13. Myrcia riodocensis

12'. Calyx 5-merous; fruits costate or not. If calyx 4-merous, then fruits costate..... 13

13. Leaf blades oblong; bracts $0.5-0.8 \mathrm{~cm}$, bracteoles ca. $0.25 \mathrm{~cm}$; fruits $1.2-1.5 \mathrm{~cm}$

2.2. Myrcia eumecephylla

13'. Leaf blades elliptic to narrowly elliptic; bracts $0.2-0.4 \mathrm{~cm}$, bracteoles $0.05-0.2 \mathrm{~cm}$; fruits $0.3-1 \mathrm{~cm}$...

14. Calyx lobes acute

2.12. Myrcia racemosa

14'. Calyx lobes obtuse to rounded 15

15. Calyx 4-5-merous, fruits costate.

2.15. Myrcia stellaris

15'. Calyx 5-merous, fruits not costate 16

16. Leaf blades chartaceous, apex acute to short-acuminate; flower buds obovoid; fruits $0.3-0.5 \mathrm{~cm}$ diam., not pruinose. 2.6. Myrcia multiflora

16 '. Leaf blades variously textured, apex acuminate; flower buds globose; fruits $0.5-0.8 \mathrm{~cm}$ diam., pruinose or not. If leaves with short-acuminate apex, then leaf texture coriaceous and fruits pruinose. 17

17. Leaf blades chartaceous, secondary veins $12-18$ pairs, inner marginal vein $0.1-0.2 \mathrm{~cm}$ distant from margin; bracts lanceolate, fruits not pruinose..

2.1. Myrcia amazonica

17'. Leaf blades coriaceous, secondary veins $18-22$ pairs, inner marginal vein 0.2-0.4 distant from margin; bracts narrowly lanceolate, fruits pruinose 2.5. Myrcia insularis

2.1. Myrcia amazonica DC., Prodr. 3: 250. 1828. Myrcia lundiana Kiaersk., Enum. Myrt. Bras. 78. 1893.

Shrubs or trees 3-15 m. Leaves with petiole $0.3-0.7 \mathrm{~cm}$ long; blade discolourous, elliptic, $2-10 \times 1.2-4.2 \mathrm{~cm}$, chartaceous, glabrous or with yellow, sparsely distributed trichomes, these usually concentrated along the midvein; apex acuminate; base attenuate to obtuse; midvein sulcate adaxially and raised abaxially; secondary veins $12-18$ pairs, flat to raised on both surfaces, marginal veins two, the inner $0.1-0.2 \mathrm{~cm}$ from the margin. Inflorescences $2.5-9.5 \mathrm{~cm}$ long, axillary or terminal, with reddish indumentum on the rachis, sparse to dense, or lacking; branching alternate or sub-opposite; bracts lanceolate, ca. $0.4 \mathrm{~cm}$ long, bracteoles lanceolate, ca. $0.05 \mathrm{~cm}$ long. Flower buds globose, $0.15-0.3 \mathrm{~cm}$ long, glabrous; calyx open, with 5 free lobes, these obtuse to rounded, $0.05-0.1 \mathrm{~cm}$ long. Fruits globose, $0.5-0.7 \mathrm{~cm}$ diam., not pruinose, not costate, glabrous, crowned by the hypanthium tube and the calyx.

Examined material: campo nativo, aceiro Catelã Jueirana, 29.VIII.2001, D.A. Folli 4032 (CVRD, RB); floresta densa [provavelmente mata alta], A.L. Peixoto et al. 3544 (RB); mata alta, estrada 143, km 0,150, talhão 403, I.A. Silva 12 (RB); estrada 142, talhão 302, A.M. Lino 112 (RB); Mussununga, estrada Orelha-de-onça, 13.XII.1994, D.A. Folli 2438 (CVRD).

Myrcia amazonica is widespread in Brazil, occurring in several vegetation types (Santos et al. 2020). In the VNR it can be found in the campo nativo and in mata alta and mussununga forests. Flowering material was collected in January and fruiting material was collected in December. It can be distinguished from other species of Myrcia sect. Aulomyrcia in the VNR by reddish indumentum and long inflorescences with many small flowers; most dried collections also have reddish-brown leaves. Specimens of this species collected in the study site state may be identified as Myrcia lundiana in herbaria, a synonym of $M$. amazonica (Lucas et al. 2016).

2.2. Myrcia eumecephylla (O.Berg) Nied., Nat. Pflanzenfam. 3(6): 74. 1895.

Myrcia limae G.M.Barroso \& Peixoto, Acta Bot. Bras. 4(2): 11. 1990. 
Shrubs or treelets 2-3 m. Leaves with petiole 0.6-1.5 cm long; blade discolourous, oblong, 8-32 $\times 2-8 \mathrm{~cm}$, chartaceous, glabrous or with yellow, sparsely distributed trichomes, these usually concentrated along the midvein; apex acuminate, base obtuse; midvein flat or raised adaxially and raised abaxially, secondary veins $12-30$ pairs, flat to raised on both surfaces, marginal veins two, the inner $0.2-0.8 \mathrm{~cm}$ from the margin. Inflorescences $3.5-9 \mathrm{~cm}$ long, axillary or terminal, with yellowishbrown indumentum on the rachis, dense; branching alternate to opposite; bracts lanceolate, $0.5-0.8$ $\mathrm{cm}$ long, bracteoles lanceolate, ca. $0.25 \mathrm{~cm}$ long. Flower buds globose, ca. $0.3 \mathrm{~cm}$ long, indumentum yellow; calyx open, with 5 free lobes, these obtuse to rounded, $0.1-0.15 \mathrm{~cm}$ long. Fruits globose, $1.2-1.5 \mathrm{~cm}$ diam., not pruinose, not costate, indumentum present, crowned by remains of the calyx.

Examined material: capoeirão, estrada municipal do MME, 14.X.2004, G.S. Siqueira 121 (CVRD); mata alta, estrada Alameda, 6.XII.2001, D.A. Folli 4138 (CVRD).

Myrcia eumecephylla is distributed from BA to ES states, in the Atlantic domain (Santos et al. 2020). In the VNR it occurs in the mata alta forests and disturbed, secondary vegetation. Flowers were collected in December and fruits were collected in October. It is recognized among other species of Myrcia sect. Aulomyrcia of the study site by large leaves with thick midvein, inflorescences with underdeveloped secondary branching at the distal half, appearing spiciform, and small flowers. The synonym Myrcia limae was described using specimens collected near the VNR (Lucas et al. 2016) and may be found applied to herbarium specimens of this species as well.

\subsection{Myrcia excelsa T.Fern. \& Gaem, Phytotaxa} 501: 293. 2021.

Trees $20-28 \mathrm{~m}$. Leaves with petiole $0.2-0.6$ $\mathrm{cm}$ long; blade discolourous, ovate to oblong, $6.5-16.5 \times 2.5-5 \mathrm{~cm}$, coriaceous, glabrous on both surfaces; apex acuminate, base obtuse, rounded or cordate; midvein raised on both surfaces, secondary veins 14-22 pairs, raised on both surfaces, marginal veins two, the inner $0.2-0.4$ $\mathrm{cm}$ from the margin. Inflorescences $5-19.5 \mathrm{~cm}$ long, axillary or terminal, glabrous on the rachis; branching alternate to opposite; bracts lanceolate, $0.4-0.5 \mathrm{~cm}$ long, bracteoles lanceolate, ca. 0.15 $\mathrm{cm}$ long. Flower buds obovoid, ca. $0.4 \mathrm{~cm}$ long, glabrous; calyx partly closed, opening in 4 regular lobes, these obtuse to rounded, not measured.
Fruits globose, $1.2-1.5 \mathrm{~cm}$ diam., not pruinose, not costate, glabrous, remnants of the calyx deciduous or persistent.

Examined material: mata alta, aceiro LASA, 26.IX.2006, D.A. Folli 5360 (CVRD); 28.IX.2006, G.S. Siqueira 246 (CVRD); estrada da Gávea, 20.VII.1979, D.A. Folli 8/179 (CVRD); 22.XI.1988, D.A. Folli 818 (CVRD); estrada do Flamengo, 2.VI.1972, A.M. Lino 78 (CVRD, RB).

Myrcia excelsa known from the Atlantic forest of Espírito Santo state only (Gaem et al. 2021a), where flowering individuals were collected in June and July and fruiting individuals were collected in September and November. This species is composed by tall trees with coriaceous leaves and glabrous inflorescences, resembling Myrcia riodocensis in reddish-brown colour of herbarium material and 4-merous calyx, but differing in leaves with midvein raised adaxially ( $v s$. sulcate in $M$. riodocensis) and flowers with calyx basally fused ( $v s$. completely free in $M$. riodocensis). When compared with Myrcia riodocensis, M. excelsa also has a tendency for smaller leaf blades.

2.4. Myrcia excoriata (Mart.) E.Lucas \& C.E.Wilson, Ann. Missouri Bot. Gard. 101: 664. 2016.

Marlierea excoriata Mart., Flora 20 (Beibl. 2): 88. 1837.

Fig. 9e

Trees 3-7 m. Leaves with petiole $0.3-1 \mathrm{~cm}$ long; blade discolourous, elliptic to oblong, 5.5$15.5 \times 1.3-6.3 \mathrm{~cm}$, chartaceous, glabrous or with light brown trichomes, tjese usually concentrated along the midvein adaxially and with yellow, sparse to dense trichomes in the whole blade abaxially; apex acuminate to long-acuminate, base cuneate to obtuse; midvein sulcate adaxially and raised abaxially; secondary veins 10-14 pairs, inconspicuous on both surfaces, marginal veins two, the inner $0.1-0.5 \mathrm{~cm}$ from the margin. Inflorescences 5-10 cm long, axillary or terminal, with yellow indumentum on the rachis, sparse to dense; branching alternate to opposite; bracts lanceolate, ca. $0.2 \mathrm{~cm}$ long, bracteoles lanceolate, $0.05-0.2 \mathrm{~cm}$ long. Flower buds globose, $0.15-0.4$ $\mathrm{cm}$ long, glabrous or with yellow, sparse trichomes; calyx completely closed, apex conic, opening in 4 irregular lobes. Fruits globose, $0.4-1.7 \mathrm{~cm}$ diam., not pruinose, not costate, glabrous or with sparse indumentum, crowned by remains of the hypanthial tube and the calyx.

Examined material: mata alta, aceiro Catelã - Jueirana, 27.X.2005, D.A. Folli 5113 (CVRD); aceiro com Adair Campo, 14.X.2002, K. Matsumoto 814 (CVRD); 
14.X.2002, D.A. Folli 4378 (CVRD, RB); estrada Bomba D'água, 14.VII.2009, G.S. Siqueira 245 (CVRD); estrada Caingá, 7.VI.1994, D.A. Folli 2321 (CVRD); 15.X.2002, K. Matsumoto 821 (CVRD); estrada Cinco Folhas, 1.IV.2012, J.E.Q. Faria \& V.G. Staggemeier 2533 (CVRD); estrada Ipê-amarelo, 22.I.2008, D.A. Folli 5914 (CVRD); estrada Jueirana Vermelha, 11.I.1994, D.A. Folli 2161 (CVRD); estrada Mantegueira, 12.I.2007, D.A. Folli 5445 (CVRD); 29.III.2012, J.E.Q. Faria et al. 2495 (CVRD).

Myrcia excoriata occurs from BA to SC, in the Atlantic domain (Santos et al. 2020). This species was collected in the mata alta forest within the VNR with flowers in October and fruits in March, April, June, and July. This species has completely closed calyx in flower buds forming a conic apex; at anthesis, it tears through the staminal disc givin a star-like appearance, as in Myrcia neoestrellensis (Fig. 2f).

2.5. Myrcia insularis Gardner, London J. Bot. 1: 536. 1842.

Trees $2.5-16 \mathrm{~m}$. Leaves with petiole $0.3-0.8$ $\mathrm{cm}$ long; blade discolourous, elliptic or ovate, $6.5-17.5 \times 2-5.2 \mathrm{~cm}$, coriaceous, with sparse, light brown indumentum on both surfaces; apex shortacuminate to acuminate, base attenuate; midvein sulcate adaxially and raised abaxially, secondary veins $18-22$ pairs, raised on both surfaces, marginal veins two, the inner $0.2-0.4 \mathrm{~cm}$ from the margin. Inflorescences $7.5-14 \mathrm{~cm}$ long, axillary or terminal, with yellowish-brown indumentum on the rachis; branching alternate or sub-opposite; bracts narrowly lanceolate, ca. $0.4 \mathrm{~cm}$ long, bracteoles narrowly lanceolate, $0.05-0.2 \mathrm{~cm}$ long. Flower buds globose, not measured, glabrous; calyx open, with 5 free lobes, these rounded, not measured. Fruits globose, $0.5-0.8 \mathrm{~cm}$ diam., pruinose, not costate, glabrous, crowned by the hypanthial tube and the calyx.

Examined material: mata alta, aceiro ao final da estrada da Gávea, 26.I.2017, K.S. Valdemarin et al. 891 (ESA, SP).

Additional material: BRAZIL. ESPÍRITO SANTO: Linhares, Lagoa Juparaná, 13.X.1992, G. Hatschbach et al. 58026 (MBM); 13.X.2002, K. Matsumoto 809 (UEC).

Myrcia insularis has been registered from PE to PR states, in ombrophyllous forests and coastal forest on sandy soils (restingas) of the Atlantic domain (Santos et al. 2020). This species has been collected in the study site in the mata alta forests with fruits in January. It is similar to Myrcia amazonica, differing in coriaceous leaf blades ( $v s$. chartaceous in the latter) with 18-22 pairs of lateral veins (vs. 12-18 in the latter) and yellowish-brown indumentum on inflorescences (vs. reddish in the latter); the former species also has a tendency for broader leaves. In addition, Myrcia insularis is the only species of the genus in the VNR with pruinose fruits. Specimens collected in Linhares municipality have more delicate leaves in comparison with the type specimen (G. Gardner 202 at BM herbarium), but they are very similar in well-developed inflorescences bearing many small flowers.

2.6. Myrcia multiflora (Lam.) DC., Prodr. 3: 244. 1828.

Fig. 3a

Shrubs or trees 2-12 m. Leaves with petiole $0.15-0.5 \mathrm{~cm}$ long; blade slightly discolourous, elliptic, $1.8-9 \times 1.1-3.2 \mathrm{~cm}$, chartaceous, glabrous or with light brown, sparsely distributed trichomes on both surfaces; apex acute to short-acuminate, base cuneate to obtuse or occasionally rounded; midvein flat to sulcate adaxially and raised abaxially, secondary veins $12-24$ pairs, slightly raised on both surfaces, marginal veins two, the inner $0.05-0.15 \mathrm{~cm}$ from the margin. Inflorescences $2-10.5 \mathrm{~cm}$ long, axillary or terminal, glabrous or with light brown, sparsely distributed trichomes on the rachis; branching alternate or sub-opposite; bracts lanceolate, $0.3-0.4 \mathrm{~cm}$ long, bracteoles lanceolate, $0.05-0.1 \mathrm{~cm}$ long. Flower buds obovoid, ca. $0.2 \mathrm{~cm}$ long, glabrous; calyx open, with 5 free lobes, these obtuse to rounded, ca. $0.05 \mathrm{~cm}$ long. Fruits globose, $0.3-0.5 \mathrm{~cm}$ diam., not pruinose, not costate, glabrous, crowned by the calyx.

Examined material: campo nativo, aceiro Eucaliptus, 3.X.2003, D.A. Folli 4617 (CVRD); estrada Bomba d'água, 23.X.1985, G.L. Farias 88 (CVRD, RB); 20.I.2008, D.A. Folli 6237 (CVRD); estrada do Flamengo, 25.X.2010, T.B. Flores \& G.S. Siqueira 940 (CVRD, ESA, RB); estrada Paraju, 14.X.2002, K. Matsumoto 817 (CVRD); mata alta, aceiro CatelãJueirana, 10.XII.2016, K.S. Valdemarin et al. 343 (ESA, SORO); 12.XII.2016, K.S. Valdemarin et al. 404 (ESA, SORO); estrada Mantegueira, 11.XII.2016, K.S. Valdemarin et al. 389 (ESA, SORO); Mussununga, aceiro Catelã - Jueirana, 27.XII.1988, G.L. Farias 252 (CVRD, RB); estrada Boleira, 5.X.2004, D.A. Folli 4956 (CVRD); estrada do Flamengo, 9.II.2000, D.A. Folli 3570 (CVRD); 22.XI.2005, D.A. Folli 5138 (CVRD); estrada Mantegueira, 12.XI.2002, D.A. Folli 4399 (CVRD); 30.XI.2006, E. Lucas 824 (CVRD, ESA, RB).

Myrcia multiflora is widespread, occurring in a series of vegetation types in most Brazilian states (Santos et al. 2020). In the VNR it was collected in campo nativo and in mata alta and 

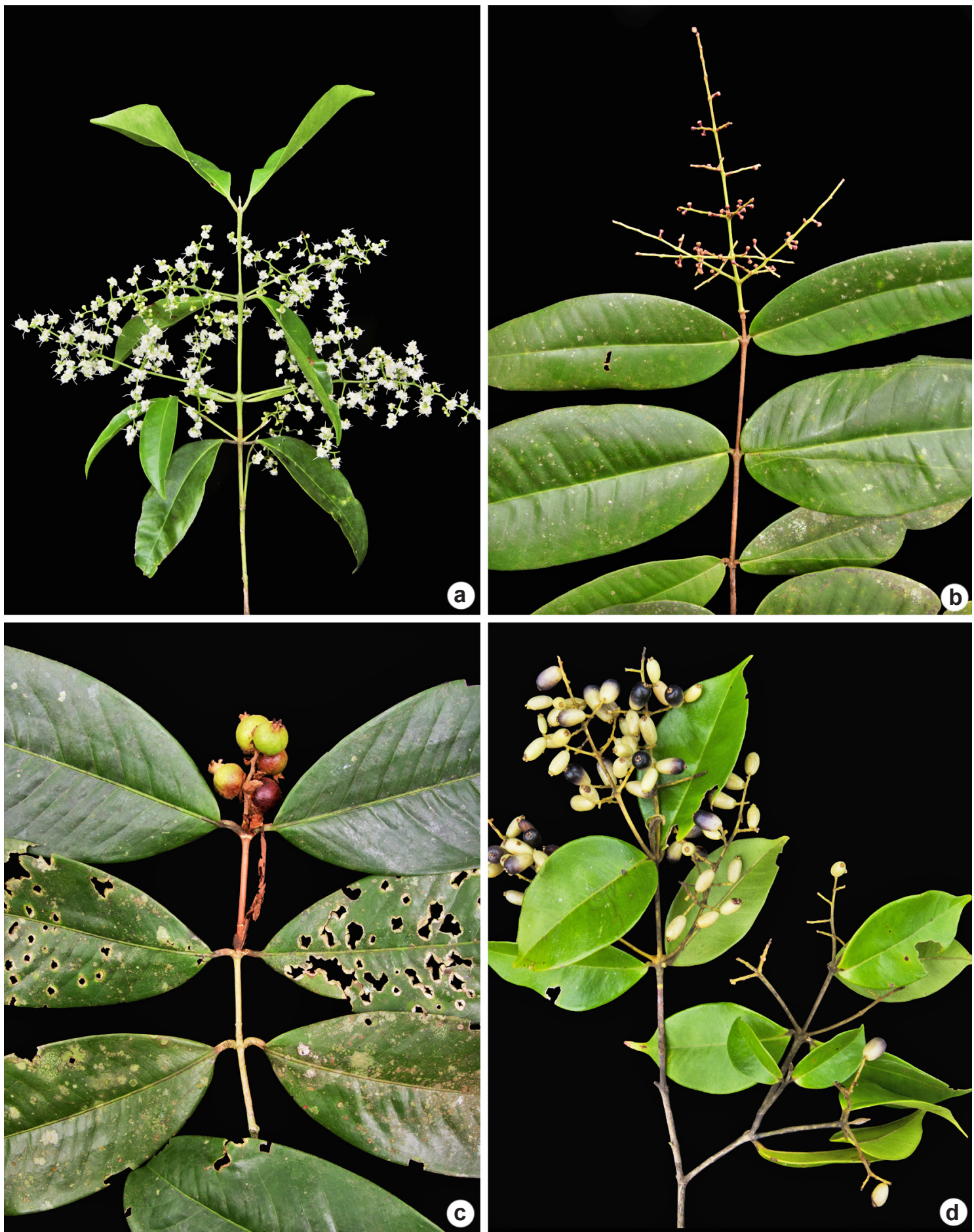

Figure 3 - a-c. Myrcia sect. Aulomyrcia - a. M. multiflora; b. M. riodocensis; c. M. sucrei. d. M. sect. Myrcia - M. splendens. 
mussununga forests. Flowering material was collected in October to December and fruiting material was collected in January and February. It resembles Myrcia amazonica in well-developed inflorescences with many flowers, but the leaves of the former usually dry greenish (vs. reddish in the latter). Myrcia multiflora is also similar to $M$. racemosa, differing in acute to short-acuminate leaves ( $v s$. acuminate to long-acuminate in $M$. racemosa) and calyx lobes obtuse to rounded (vs. acute in $M$. racemosa).

2.7. Myrcia neoestrellensis E.Lucas \& C.E.Wilson, Ann. Missouri Bot. Gard. 101: 678. 2016.

Marlierea estrellensis O.Berg, Fl. bras. 14: 34. 1857.

Fig. 2d-f

Trees $17-22 \mathrm{~m}$. Leaves with petiole $0.5-0.95$ cm long; blade discolourous, elliptic to obovate, $6-8.5 \times 2.5-3.5 \mathrm{~cm}$, slightly coriaceous, glabrous or with sparse, yellow indumentum on both surfaces; apex acute to short-acuminate, base cuneate; midvein flat to sulcate adaxially and raised abaxially, secondary veins $8-10$ pairs, raised on both surfaces, marginal veins two, the inner $0.15-0.2 \mathrm{~cm}$ from the margin. Inflorescences 2-7.5 $\mathrm{cm}$ long, terminal, glabrous on the rachis; branching alternate or sub-opposite; bracts not seen, bracteoles lanceolate, ca. $0.1 \mathrm{~cm}$ long. Flower buds globose, 0.25-0.35 cm diam., glabrous; calyx completely closed, apex rounded, opening in 4 irregular lobes. Fruits not seen.

Examined material: Mata alta, estrada da Gávea, 2.VI.1981, D.A. Folli 319 (CVRD, RB); estrada Orelhade-onça, 9.XI.1982, D.A. Folli 403 (CVRD, RB).

Myrcia neoestrellensis occus in the Atlantic forest of ES and RJ states (Lucas et al. 2016; Santos et al. 2020). It occurs in the mata alta forest within the VNR, where flowering material was collected in June and November; fruits are still lacking in the consulted herbaria. This species is distinguished by congener species of the study site by conspicuous dark glands on the leaves and flower buds, the latter completely enclosed by the calyx.

2.8. Myrcia neoregeliana E.Lucas \& C.E.Wilson, Ann. Missouri Bot. Gard. 101: 680. 2016.

Marlierea regeliana O.Berg, Fl. bras. 14: 537. 1859.

Trees 6-20 m. Leaves with petiole 0.6-1 $\mathrm{cm}$ long; blade discolourous, elliptic, 8-10.5 $\times$ $2.8-5 \mathrm{~cm}$, chartaceous, glabrous on both surfaces; apex short-acuminate to acuminate, base cuneate; midvein flat to sulcate adaxially, raised abaxially, secondary veins $12-18$ pairs, inconspicuous adaxially and raised abaxilly, marginal veins two, the inner $0.15-0.4 \mathrm{~cm}$ from the margin. Inflorescences $4.2-9.5 \mathrm{~cm}$ long, terminal, with brown, sparsely distributed trichomes on the rachis, branching opposite or sub-opposite; bracts not seen; bracteoles lanceolate, $0.15-0.2 \mathrm{~cm}$ long. Flower buds globose, $0.2-0.4 \mathrm{~cm}$ long, glabrous; calyx completely closed, apex rounded, opening in 4 irregular lobes. Fruits globose, 0.9-1.2 cm diam., not pruinose, not costate, glabrous or with sparse indumentum; remnants of the calyx deciduous.

Examined material: mata alta, estrada Caingá, 23.X.1979, D.A. Folli 147 (CVRD, RB); estrada da Gávea, 30.XI.1982, I.A. Silva 367 (CVRD, RB, SP); estrada Jueirana Vermelha, 27.XI.1991, D.A. Folli 1507 (CVRD).

Additional material: BRAZIL. ESPÍRITO SANTO: Santa Teresa, Reserva Biológica de Nova Lombardia, 5.II.1985, A. Peixoto 3495 (RB).

Myrcia neoregeliana is distributed from BA to SC states, in ombrophilous forests of the Atlantic domain (Santos et al. 2020). In the VNR it was collected only in the mata alta forests. Flowering material was collected in October and November and fruiting material was collected in February. In the sense here adopted it may be hardly distinguished from M. neoestrellensis, except for the dark glands on leaves of the latter.

2.9. Myrcia neosuaveolens E.Lucas \& C.E.Wilson, Ann. Missouri Bot. Gard. 101: 682. 2016.

Marlierea suaveolens Cambess., Fl. Bras. Merid. 2: 374.1883.

Shrubs or trees 1-14 m. Leaves with petiole 0.5-0.8 cm long; blade slightly discolourous, elliptic, 4.8-9.3 × 1-2.5 cm, chartaceous, glabrous on both surfaces; apex long-acuminate, base cuneate; midvein flat to sulcate adaxially, raised abaxially, secondary veins 10-16 pairs, inconspicuous on both surfaces, marginal vein ca. $0.1 \mathrm{~cm}$ from the margin. Inflorescences $1.4-2.1 \mathrm{~cm}$ long, terminal, glabrous on the rachis; branching opposite; bracts not seen, bracteoles not seen. Flower buds globose, ca. $0.2 \mathrm{~cm}$ long, glabrous; calyx completely closed, apex rounded, opening in 4-5 irregular lobes. Fruits globose, 0.9-1 cm diam., not pruinose, not costate, glabrous; remnants of the calyx deciduous.

Examined material: mata alta, estrada Jueirana Vermelha, 11.IV.2006, G.Q. Freire et al. 145 (CVRD, ESA, RB); estrada Pelada, 16.X.2001, D.A. Folli 4093 (CVRD); mata ciliar, estrada municipal Canto Grande, 28.XI.2006, D.A. Folli 5410 (CVRD); 23.III.1986, M. Sobral 4726 (CVRD, RB). 
Myrcia neosuaveolens can be found in coastal Atlantic forest, from ES to SC states (Santos et al. 2020). Within the study site it was collected in the mata alta forests and riverine vegetation. Flowering material was collected in October and November and fruiting material was collected in March and April. This species is recognisable by delicate branches bearing long-acuminate leaves and reduced inflorescences.

2.10. Myrcia neuwiediana (O.Berg) E.Lucas \& C.E.Wilson, Ann. Missouri Bot. Gard. 101: 683. 2016.

Marlierea neuwiediana (O.Berg) Nied., Nat. Pflanzenfam. 7: 77. 1893.

Shrubs or trees $1.5-4 \mathrm{~m}$. Leaves with petiole 0.5-0.8 cm long; blade discolourous, elliptic to obovate, 3.3-12.5 × 2-6.3 cm, chartaceous, glabrous or with sparse, light brown indumentum on both surfaces; apex acute to short-acuminate or rounded, base obtuse to rounded; midvein flat adaxially, raised abaxially, secondary veins 10-14 pairs, inconspicuous adaxially and usually raised abaxially, marginal veins two, the inner $0.2-0.5$ $\mathrm{cm}$ from the margin. Inflorescences $2.5-10.5 \mathrm{~cm}$ long, axillary or terminal, with yellowish-brown indumentum on the rachis; branching alternate to opposite; bracts lanceolate, 0.5-1 cm long, bracteoles rounded to lanceolate, ca. $0.4 \mathrm{~cm}$ long. Flower buds obovoid, ca. $0.4 \mathrm{~cm}$ long, with yellowish-brown indumentum; calyx completely closed, apex rounded, opening in 5 irregular lobes. Fruits globose, $0.4-0.6 \mathrm{~cm}$ diam., not pruinose, not costate, with indumentum, crowned by remnants of the calyx.

Examined material: campo nativo, aceiro Ceolin, 12.XI.2001, D.A. Folli 4118 (CVRD, RB); estrada Paraju, 31.I.2017, K.S. Valdemarin \& T.B. Flores 949 (ESA, SORO); mata alta, aceiro Catelã - João Pedro, 14.X.2002, K. Matsumoto 815 (CVRD); 10.XII.2016, K.S. Valdemarin et al. 351 (ESA, SORO); Mussununga, aceiro Arlindinho, 20.IX.2012, G.S. Siqueira 797 (CVRD, RB); estrada do Flamengo, 14.II.2000, D.A. Folli 3573 (CVRD); transição entre campo nativo e mussununga, estrada Jueirana Vermelha, 25.I.2017, K.S. Valdemarin et al. 839 (ESA, SORO).

Myrcia neuwiediana is distributed from SE to ES states, in sandy coastal vegetation of the Atlantic domain (Santos et al. 2020). However, this species has been registered in campo nativo and mata alta and mussununga forests in the study site, where flowering material was collected in September to December and fruiting material was collected in January and February. This species has remarkable, well-developed bracteoles that enfold the whole flower bud in initial development stages, also persisting after anthesis.

2.11. Myrcia obversa (D.Legrand) E.Lucas \& C.E.Wilson, Ann. Missouri Bot. Gard. 101: 684. 2016.

Marlierea obversa D.Legrand, Comun. Bot. Mus. Hist. Nat. Montevideo 3(40): 28. 1962. Fig. 4a

Trees 2-14 m. Leaves with petiole $0.6-1.5 \mathrm{~cm}$ long; blade discolourous, oblong, 14.5-32.5 × 4-6 $\mathrm{cm}$, chartaceous, with sparse, yellow indumentum on both surfaces; apex acuminate, base cuneate; midvein raised on both surfaces, secondary veins 20-40 pairs, raised on both surfaces, marginal veins two, the inner $0.2-0.4 \mathrm{~cm}$ from the margin. Inflorescences $7-12.5 \mathrm{~cm}$ long, terminal, with yellow, dense indumentum on the rachis; branching alternate or sub-opposite; bracts lanceolate, ca. $0.8 \mathrm{~cm}$ long, bracteoles rounded to lanceolate, 0.5-0.7 cm long. Flower buds obovoid, ca. 0.6 $\mathrm{cm}$ long, with dense, yellow indumentum; calyx partly closed, opening in 4-5 regular lobes. Fruits globose, 0.8-2 cm diam., not pruinose, not costate, with sparse to dense indumentum, crowned by remnants of the calyx.

Examined material: mata alta, 28.X.2010, T.B. Flores \& G.S. Siqueira 956 (CVRD, ESA, RB, SORO); Mussununga, estrada Jacarandá, 16.V.1978, I.A. Silva 2 (CVRD); 8.XII.1988, G.L. Farias 250 (CVRD).

The geographical range of Myrcia obversa extends from BA to RJ states, in restingas and ombrophilous forests of the Atlantic domain (Santos et al. 2020). In the VNR it occurs in the mata alta and mussununga forests. Flowers were collected in May and fruits were collected in October and December. There may be confusion between this species and Myrcia eumecephylla because both have large, oblong leaves with thick midvein, but $M$. obversa has greater flower buds (ca. $0.6 \mathrm{~cm} v s$. ca. $0.3 \mathrm{~cm}$ in M. eumecephylla) with 4-5 partly fused calyx lobes ( $v s .5$, completely free in M. eumecephylla); indumentum on reproductive organs also differ, being bright and silky in Myrcia obversa and pale, pubescent or tomentose in $M$. eumecephylla.

2.12. Myrcia racemosa (O.Berg) Kiaersk., Enum. Myrt. Bras. 72. 1893.

Myrcia acuminatissima O.Berg, Fl. bras. 14: 167. 1857.

Fig. 4d

Shrubs or trees $2-13 \mathrm{~m}$. Leaves with petiole 0.2-0.7 cm long; blade concolourous, elliptic to 
narrowly elliptic, 3-12 × 1-5 cm, chartaceous, glabrous or with sparse, light brown indumentum on both surfaces; apex acuminate to long-acuminate, base cuneate to obtuse; midvein usually raised on both surfaces, secondary veins $10-14$ pairs, slightly raised on both surfaces, marginal veins two, the inner $0.05-0.2 \mathrm{~cm}$ from the margin. Inflorescences 1-10.5 cm long, axillary or terminal, with light brown, sparse to dense indumentum on the rachis; branching alternate to sub-opposite; bracts not seen,
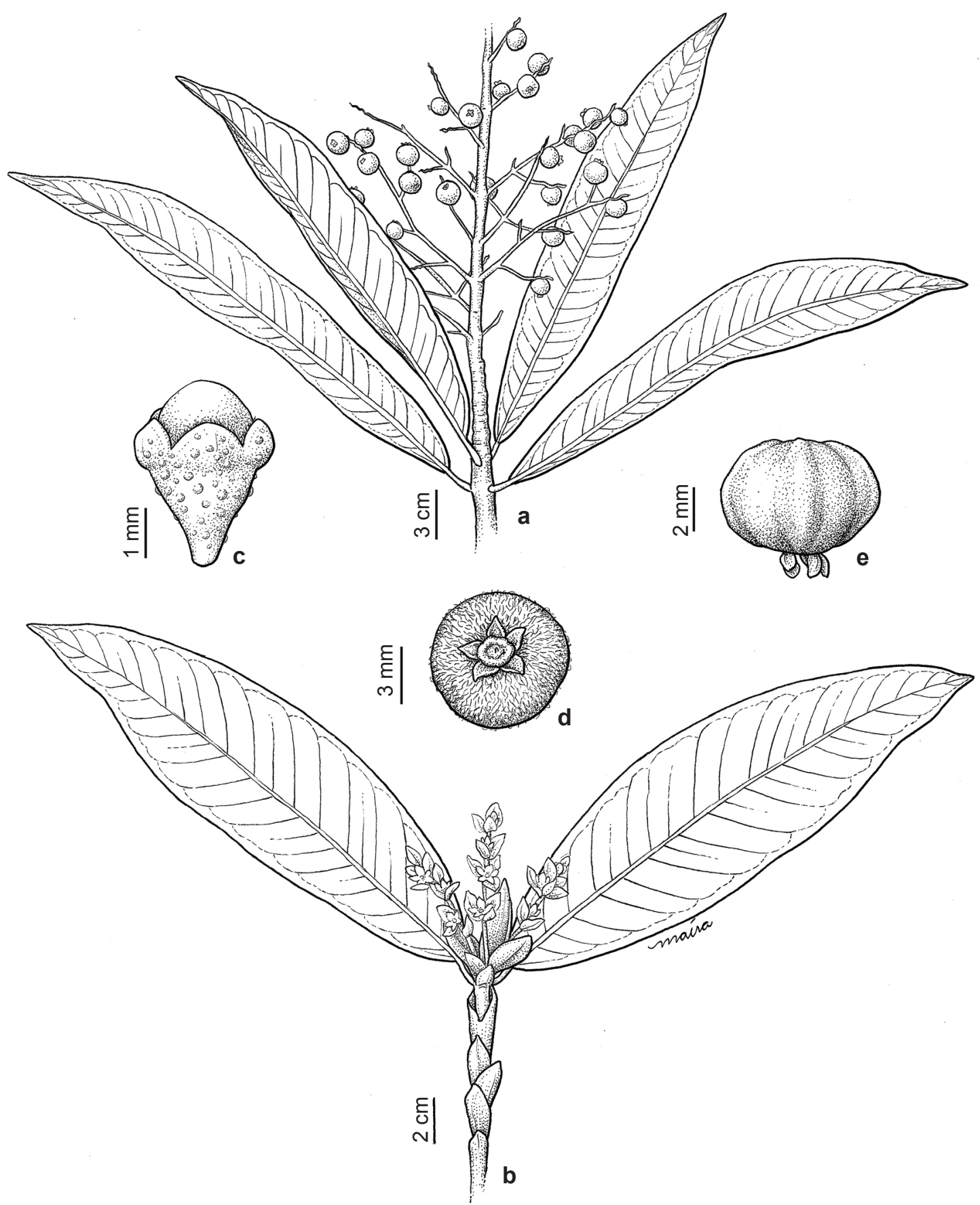

Figure 4 - a. Myrcia obversa - branch. b. M. sucrei - branch. c. M. gilsoniana - flower bud. d. M. racemosa - fruit (depicted inverted). e. M. stellaris - fruit. 
bracteoles lanceolate to narrowly lanceolate, ca. $0.15 \mathrm{~cm}$ long. Flower buds turbinate, ca. $0.25 \mathrm{~cm}$ long, with dense, light brown indumentum; calyx open, with 5 free lobes, these acute, ca. $0.1 \mathrm{~cm}$ long. Fruits globose, $0.4-1 \mathrm{~cm}$ diam., not pruinose, not costate, with sparse to dense indumentum, crowned remnants of the calyx.

Examined material: mata alta, estrada Jacarandá, 15.XII.1982, I.A. Silva 378 (CVRD, RB); mata ciliar, aceiro com represa, 24.IV.2008, D.A. Folli 6048 (CVRD, RB); aceiro Milanês, 11.III.2013, D.A. Folli 7026 (CVRD); Mussununga, aceiro com BR-101, 11.VII.2005, D.A. Folli 5077 (CVRD); 11.VII.2005, D.A. Folli 5079 (CVRD); estrada Paraju, 4.II.1993, G.L. Farias 597 (CVRD); várzea periodicamente inundada, estrada da Gávea, 11.V.2005, R. Reis 6 (CVRD); várzea permanentemente inundada, estrada da Gávea, 20.VI.2000, D.A. Folli 3638 (CVRD).

Myrcia racemosa occurs in coastal vegetation of the Atlantic domain, from PE to SC states (Santos et al. 2020). In the VNR it was registered in the mata alta and mussununga forests, flooded areas, and riparian vegetation. Flowers were collected in February and December and fruits were collected from February to July. It is separated from Myrcia multiflora by acuminate or long-acuminate leaves ( $v s$. acute to short-acuminate in $M$. multiflora) and acute calyx lobes (vs. obtuse to rounded in $M$. multiflora); inflorescences are also usually longer in the latter species. Myrcia acuminatissima, a synonym of $M$. racemosa, is a frequent name in herbarium specimens of this species.

\subsection{Myrcia riodocensis G.M.Barroso \& Peixoto,} Acta Bot. Bras. 4(2): 13. 1990.

Fig. $3 b$

Trees 4-10 m. Leaves with petiole $0.3-0.5 \mathrm{~cm}$ long; blade slightly discolourous, elliptic or oblong, 8-20 × 4-6.5 cm, coriaceous, glabrous on both surfaces or with sparse, light brown indumentum abaxially; apex acute to acuminate, base obtuse to rounded or cordate; midvein sulcate adaxially, raised abaxially, secondary veins $16-20$ pairs, raised on both surfaces, marginal veins two, the inner $0.15-0.4 \mathrm{~cm}$ from the margin. Inflorescences 3.5-11 cm long, terminal, with yellow, sparse indumentum on the rachis; branching alternate to opposite; bracts lanceolate, $0.25-0.5 \mathrm{~cm}$ long, bracteoles lanceolate to narrowly lanceolate, $0.1-0.15 \mathrm{~cm}$ long. Flower buds turbinate, 0.2-0.4 $\mathrm{cm}$ long, with sparse, yellow indumentum; calyx open, with 4 free lobes, these apiculate to rounded, $0.1-0.15 \mathrm{~cm}$ long. Fruits globose, $0.1-1.5 \mathrm{~cm}$ diam., not pruinose, not costate, glabrous, crowned by remnants of the calyx.
Examined material: capoeirão, estrada municipal do MME, 16.VI.2004, D.A. Folli 4866 (CVRD); mata alta, aceiro Calimã, 7.V.2001, D.A. Folli 3918 (CVRD); estrada Mantegueira, 3.X.2014, G.S. Siqueira 1008 (CVRD, RB); trilha próxima à antiga torre, 22.III.2019, K.S. Valdemarin et al. 1225 (ESA); 30.I.1972, D. Sucre 8269 (CVRD, RB, SP).

Myrcia riodocensis is endemic to the Atlantic forest of ES state (Santos et al. 2020). In the study site it was collected in mata alta forests and anthropic secondary forests. Flowering material was collected in June and fruiting material was collected in October. It can be recognised by reddish, exfoliating bark in mature branches, glabrous or glabrate reddish leaves, and flowers with 4-merous calyx with unequal lobes.

2.14. Myrcia scytophylla (Diels) E.Lucas \& C.E.Wilson, Ann. Missouri Bot. Gard. 101: 692. 2016.

Marlierea scytophylla Diels, Verh. Bot. Vereins Prov. Brandenburg 48: 187. 1907.

Trees $12-18 \mathrm{~m}$. Leaves with petiole $0.4-0.8$ cm long; blade concolourous, elliptic to obovate or occasionally oblong, 3.5-9.5 × 1.6-3.5 cm, chartaceous, glabrous on both surfaces or with sparse, yellow indumentum concentrated along the midvein abaxially; apex short-acuminate to acuminate or rarely rounded, base cuneate to obtuse; midvein raised on both surfaces, secondary veins $12-14$ pairs, raised on both surfaces, marginal veins two, the inner $0.15-0.25 \mathrm{~cm}$ from the margin. Inflorescences $2-8.5 \mathrm{~cm}$ long, axillary or terminal, with yellow, sparse indumentum on the rachis; branching alternate or sub-opposite; bracts lanceolate, ca. $0.2 \mathrm{~cm}$ long. bracteoles lanceolate, $0.05-0.1 \mathrm{~cm}$ long. Flower buds turbinate, 0.2-0.3 cm long, glabrous; calyx open, with 5 free lobes, these rounded, not measured. Fruits globose, ca. $1 \mathrm{~cm}$ diam., not pruinose, not costate, glabrous, crowned by remnants of the calyx.

Examined material: mata alta, aceiro Marco de Ferro, 20.V.2009, D.A. Folli 6354 (CVRD); estrada da Gávea, 7.IV.1978, J. Spada 75 (CVRD); estrada Caingá, 15.I.1982, I.A. Silva 308 (CVRD, RB); estrada Farinha Seca, 20.IX.1982, D.A. Folli 397 (CVRD, RB); estrada Macanaíba Pele de Sapo, 2.IV.2008, M.C. Souza 655 (CVRD).

Myrcia scytophylla was hitherto known from collections from northern Brazil, in the Amazonian domain (Santos et al. 2020); it is here reported in the Atlantic domain for the first time. This species has been collected in the mata alta forests of the VNR with flowers in January, April, 
and May, and fruits in September. Despite having flowers with 4-merous calyx and slightly broader leaves, the Amazonian collections are otherwise nearly indistinguishable from the material here examined.

\subsection{Myrcia stellaris Gaem \& Mazine Brittonia} 73: 305. 2021.

Fig. 4e

Trees 4-5 m. Leaves with petiole $0.4-1 \mathrm{~cm}$ long; blade concolourous, elliptic to narrowly elliptic, $4.5-10.5 \times 2.5-4.5 \mathrm{~cm}$, slightly coriaceous, glabrous on both surfaces; apex acuminate, base cuneate to obtuse; midvein flat to sulcate adaxially, raised abaxially; secondary veins $10-18$ pairs, raised on both surfaces, marginal veins two, the inner $0.15-0.3 \mathrm{~cm}$ from the margin. Inflorescences 2-7.5 cm long, axillary or terminal, glabrous on the rachis; branching alternate or sub-opposite; bracts ovate, ca. $0.2 \mathrm{~cm}$ long, bracteoles not seen. Flower buds globose, ca. $0.3 \mathrm{~cm}$ long, glabrous; calyx open or fused only at the base opening in (4-)5 regular lobes, these rounded, ca. $0.1 \mathrm{~mm}$. Fruits globose or oblate, 0.5-0.7 long, not pruinose, conspicuously costate, glabrous, crowned by hypanthium tube and the calyx.

Examined material: capoeirão, estrada municipal MME, 15.XII.2008, D.A. Folli 6259 (CVRD, SORO); mata alta, estrada Caingá, 30.XII.2003, D.A. Folli 4726 (CVRD, SORO); estrada Cinco Folhas, 27.I.2017, K.S. Valdemarin et al. 915 (ESA, SORO); estrada municipal MME, 26.XII.2013, D.A. Folli 7161 (CVRD, RB, SORO).

Myrcia stellaris is known to date only by collections made within the VNR, in the mata alta forests and disturbed vegetation (Gaem et al. 2021b). Flowering material was collected in December and fruiting material was collected in December and January. It is similar to Myrcia racemosa in overall appearance, differing mainly in glabrous inflorescence rachises and flower buds ( $v s$. with indumentum in $M$. racemosa) and 4-5-merous calyx with rounded lobes ( $v s$. 5-merous, lobes acute in $M$. racemosa).

2.16. Myrcia sucrei (G.M.Barroso \& Peixoto) E.Lucas \& C.E.Wilson, Ann. Missouri Bot. Gard. 101: 695. 2016.

Marlierea sucrei G.M.Barroso \& Peixoto, Acta Bot. Bras. 4(2): 15. 1990.

Figs. 3c; $4 b$

Trees 2-12 m. Leaves with petiole $1-1.2 \mathrm{~cm}$ long, blade discolourous, oblong, 12-29 × 6.5-13 $\mathrm{cm}$, coriaceous, with sparse to dense, golden indumentum on both surfaces; apex acuminate, base rounded; midvein raised on both surfaces, secondary veins 20-35 pairs, flat to raised on both surfaces, marginal veins two, the inner $0.3-0.6 \mathrm{~cm}$ from the margin. Inflorescences $4.5-12 \mathrm{~cm}$ long, terminal, with golden, dense indumentum on the rachis; branching alternate to opposite; bracts lanceolate, $2.5-3 \mathrm{~cm}$ long, bracteoles rounded to lanceolate, 1.2-2 cm long. Flower buds globose, $0.5-0.7 \mathrm{~cm}$ long, with dense, golden indumentum; calyx completely closed, apex rounded, opening in 5 regular lobes, these ca. $0.3 \mathrm{~cm}$ long. Fruits globose, 1-1.5 cm diam., not pruinose, not costate, with dense indumentum, crowned by remnants of the calyx.

Examined material: mata alta, estrada da Gávea, 30.XI.1982, I.A. Silva 366 (CVRD, SP); mata ciliar, aceiro Ceolin, 16.XII.2003, D.A. Folli 4706 (SORO, SPF); Mussununga, estrada do Flamengo, 31.I.2002, $P$. Fiaschi 962 (CVRD, RB); 22.III.2019, K.S. Valdemarin et al. 1222 (ESA); 31.I.1972, D. Sucre 8320 (RB, SP).

Myrcia sucrei has been registered in BA and ES states, in the Atlantic domain (Santos et al. 2020). In the study site it was collected in riverine vegetation and the mata alta and mussununga forests, where flowering samples were collected in November and fruiting samples were collected in January. It resembles Myrcia eumecephylla and $M$. obversa in large leaves with thick midveins, being distinguished mainly by flowers completely enclosed by the calyx, with indistinguishable lobes before anthesis (vs. calyx not completely closed and lobes distinguishable in the two latter species). This species also has conspicuous cataphylls and bracts and showy indumentum formed by long, golden trichomes.

3. Myrcia sect. Calyptranthes (Sw.) A.R.Lourenço \& E.Lucas, Kew Bull. 73(9): 3. 2018.

Vegetative branching sympodial. Leaves with inter-secondary and tertiary veins usually flat; blade not strongly discolourous, abaxial surface not visibly contrasting with dark dots. Inflorescences with opposite branching. Flower buds globose or obovoid; calyx completely fused in bud, opening as a calyptra; hypanthium longitudinally prolonged above the summit of the ovary, glabrous on the inner surface; flower disc glabrous, staminal ring glabrous, comprising up to $40 \%$ of the total disc width; anthers with symmetrical thecae, reversing curvature on dehiscence; ovary 2-locular, with two ovules per locule. Fruits globose, crowned by the hypanthial tube, calyx usually deciduous. 
It is estimated that 277 species belong to Myrcia sect. Calyptranthes, distributed from Central America and the Caribbean to South America (Lucas et al. 2018); six of these species occur in the VNR. This section is recognised by flowers with extended hypanthium, glabrous flower disc, and completely fused calyx, detaching transversely as a unit (i.e., a calyptra) at anthesis.

\section{Key to species of Myrcia sect. Calyptranthes in the VNR}

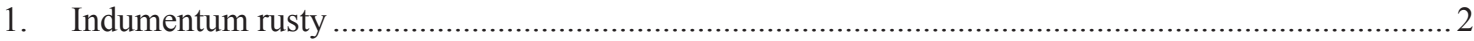

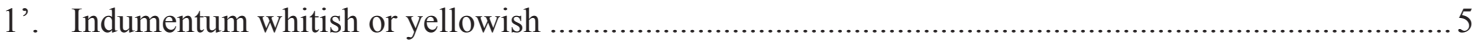

2. Leaf blades discolourous; flower buds fusiform, calyx conic................ 3.1. Myrcia cymatophylla

2'. Leaf blades concolourous; flower buds globose or obovoid, calyx apiculate or rounded ............. 3

3. Abaxial surface of leaf blades glabrous, lateral veins 16-18 pairs; flower buds globose, ca. $0.6 \mathrm{~cm}$, apex rounded ........................................................................... 3.5. Myrcia sp. 1

3'. Abaxial surface of leaf blades sparsely to densely covered with indumentum, lateral veins 8-16 pairs; flower buds obovoid, $0.2-0.4 \mathrm{~cm}$, apex apiculate .

4. Petioles ca. $0.5 \mathrm{~cm}$, leaf blades coriaceous, apex usually rounded to obtuse, base rounded, lateral veins $8-12$ pairs, marginal vein single ........................ 3.2. Myrcia loranthifolia

4'. Petioles $0.6-1.3 \mathrm{~cm}$, leaf blades chartaceous, apex acuminate, base cuneate, lateral veins 12-16 pairs, marginal veins two 3.6. Myrcia sp. 2

5. Shrubs ca. $5 \mathrm{~m}$; leaf blades glabrous abaxially; inflorescences $5.5-9 \mathrm{~cm}$, branching opposite 3.3. Myrcia neolucida

5'. Trees 5-17 m; leaf blades with whitish indumentum abaxially; inflorescences 3-6.5 $\mathrm{cm}$, branching absent (but flowers opposite on axis) 3.4. Myrcia pteropoda

3.1. Myrcia cymatophylla E.Lucas \& G.P.Burton, Phytotaxa 460: 24. 2020.

Calyptranthes blanchetiana O.Berg, Fl. bras. 14: 40. 1857.

Trees ca. $4 \mathrm{~m}$. Leaves with petiole $0.5-0.8$ cm long; blade discolourous, elliptic to ovate, 12.5-19 × 4-5.5 cm, chartaceous, glabrous on both surfaces; apex acuminate, base cuneate to slightly obtuse; midvein sulcate adaxially and raised abaxially, secondary veins $14-16$ pairs, raised on both surfaces, marginal ca. $0.2 \mathrm{~cm}$ from the margin. Inflorescences $4.5-6 \mathrm{~cm}$ long, terminal, rachis glabrous or bearing rusty indumentum; branching opposite; bracts lanceolate, ca. $1.5 \mathrm{~cm}$ long, bracteoles ovate, ca. $0.5 \mathrm{~cm}$. Flower buds fusiform, ca. $0.6 \mathrm{~cm}$, with rusty indumentum; calyx completely closed, conical, opening as a calyptra. Fruits globose, ca. $0.5 \mathrm{~cm}$ diam., not pruinose, not costate, glabrous, crowned by the hypanthial tube, calyx deciduous or persistent.

Examined material: mata alta, aceiro da divisa com ICMBio, 11.XII.2012, G.S. Siqueira 837 (CVRD, SORO).

Additional material: BRAZIL. BAHIA: Uruçuca, distrito de Serra Grande, 7,3 km na estrada Serra Grande Itacaré, fazenda Lagoa do Conjunto Santa Cruz, 7.IX.1991, A.M. Carvalho et al. 3658 (RB, CEPEC).
Myrcia cymatophylla has a disjoint distribution between the Amazon domain (PA state) and the Atlantic domain (BA state) (Lourenço et al. 2020); the occurrence of this taxon in the ES state is here reported for the first time. It was collected within the VNR in the mata alta forest with fruits in December. This species can be recognised by inflorescences with persistent bracts and fusiform flower buds opening as a conic calyptra at anthesis.

3.2. Myrcia loranthifolia (DC.) G.P.Burton \& E.Lucas, Phytotaxa 460: 36. 2020.

Calyptranthes brasiliensis Spreng., Syst. Veg., ed. 16, 2: 499. 1825.

Calyptranthes mutabilis O.Berg, Fl. bras. 14: 540. 1859.

Fig. 5a

Shrubs or trees 1-8 m. Leaves with petiole ca. $0.5 \mathrm{~cm}$ long; blade concolourous, elliptic, $3.5-8 \times 2-5 \mathrm{~cm}$, coriaceous, glabrous adaxially and with rusty, sparsely to densely distributed trichomes abaxially; apex obtuse to rounded or less often acute, base rounded; midvein sulcate adaxially and raised abaxially, secondary veins 8-12 pairs, inconspicuous adaxially and raised abaxially, marginal vein ca. $0.2 \mathrm{~cm}$ from the margin. Inflorescences 3-9 cm long, axillary, with rusty 

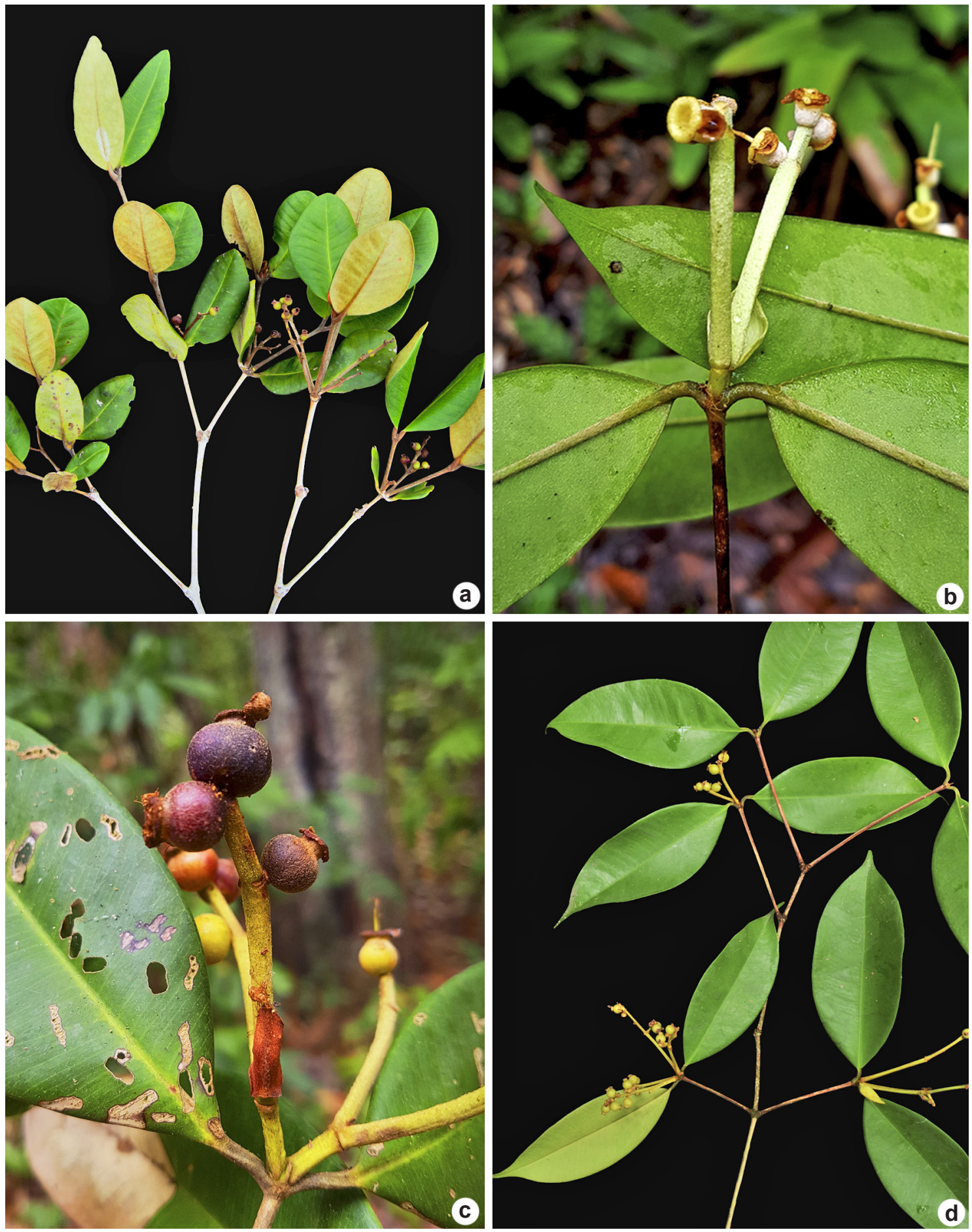

Figure 5 - a-d. Myrcia sect. Calyptranthes - a. M. loranthifolia; b-c. M. pteropoda; d. Myrcia sp.2. 
indumentum on the rachis; branching opposite; bracts not seen, bracteoles not seen. Flower buds obovoid, 0.3-0.4 cm long, with rusty indumentum; calyx completely closed, apiculate, opening as a calyptra. Fruits globose, ca. $0.5 \mathrm{~cm}$ diam., not pruinose, not costate, with sparse indumentum, crowned by the hypanthial tube.

Examined material: área de borda de floresta, estrada do Flamengo, 13.V.2009, G.D. Colletta et al. 262 (ESA, CVRD); campo nativo, estrada Bomba d'água, 27.VIII.1991, D.A. Folli 1392 (CVRD); 23.VII.2002, D.A. Folli 4301 (CVRD); estrada da Gávea, 30.I.1986, G.L. Farias 99 (CVRD, RBR); 17.I.2002, D.A. Folli 4167 (CVRD); 30.XI.2006, E.J. Lucas 888 (CVRD, ESA); 7.II.2007, J.R. Stehmann et al. 4672 (CVRD); estrada do Flamengo, 28.I.2003, V.B.R. Ferreira 9 (CVRD); 19.IX.1993, D. Sucre 11424 (CVRD); estrada Paraju, 2.XII.2006, E.J. Lucas et al. 930 (CVRD, ESA, RB, SORO); 31.I.2017, K.S. Valdemarin \& T.B. Flores 966 (ESA, SORO); Mussununga, aceiro Calimã, 25.I.2017, K.S. Valdemarin et al. 829 (ESA, SORO); estrada Bomba d'água, 21.II.2014, L. Biral 1004 (CVRD); estrada do Flamengo, 1.X.2016, K.S. Valdemarin et al. 118 (ESA, SORO); transição entre campo nativo e mussununga, aceiro Catelã, 10.XII.2016, K.S. Valdemarin et al. 346 (ESA, SORO); estrada da Gávea, 8.II.1999, E. Nic Lughadha 172 (CVRD, RB, SP); 1.X.2016, K.S. Valdemarin et al. 129 (ESA, SORO); estrada Jueirana Vermelha, 25.I.2017, K.S. Valdemarin et al. 825 (ESA, SORO).

Myrcia loranthifolia is distributed from CE to $\mathrm{SC}$ states, in various vegetation types of the Atlantic and Cerrado domains (Santos et al. 2020). In the VNR it occurs mainly in the campo nativo, mussununga forests, and transitional areas between the two latter. Flowering material was collected in January and February and fruiting material was collected in May, from July to October and in December. A series of names was relegated to the synonymy of Myrcia loranthifolia in a recent review of $M$. sect. Calyptranthes from the Atlantic domain (Lourenço et al. 2020), but we here chose to treat it in a more conservative way. In this sense, Myrcia loranthifolia is characterised in the study site by rusty indumentum on inflorescences and abaxial leaf surfaces and small leaf blades with usually obtuse or rounded apex, a form previously associated with the synonyms Calyptranthes brasiliensis and C. mutabilis.

3.3. Myrcia neolucida A.R.Lourenço \& E.Lucas, Phytotaxa 373: 79. 2018.

Calyptranthes lucida Mart. ex DC., Prodr. 3: 258. 1828.
Shrubs ca. $5 \mathrm{~m}$. Leaves with petioles $0.6-0.8$ cm long; blade discolourous, elliptic, 8-9.8 $\times$ $3.1-4.5 \mathrm{~cm}$, chartaceous, glabrous on both surfaces; apex acuminate, base obtuse; midvein sulcate adaxially and raised on abaxially, secondary veins 16-20 pairs, inconspicuous on both surfaces, marginal veins two, the inner ca. $0.1 \mathrm{~cm}$ from the margin. Inflorescences 5.5-9 cm long, axillary or terminal, with whitish to yellowish indumentum on the rachis; branching opposite; bracts not seen, bracteoles not seen. Flower buds obovoid, ca. 0.2 $\mathrm{cm}$ long (maybe young), with whitish to yellowish indumentum; calyx completely closed, apiculate, opening as a calyptra. Fruits not seen.

Examined material: várzea periodicamente inundada, estrada Sapucaia Vermelha, 23.XII.2003, D.A. Folli 4722 (CVRD).

Myrcia neolucida is widespread in Brazil and can be found in many states and vegetation types (Santos et al. 2020). This species was collected in flooded areas within the study site with flowers in December. It is recognisable by whitish to yellowish indumentum, well-developed and broadly branched inflorescences, and small flowers. The specimen collected in the VNR is an exception in the species for having moderately pubescent inflorescence branches and densely pubescent hypanthia (see Lourenço et al. 2020 for a broader approach).

3.4. Myrcia pteropoda (O.Berg) A.R.Lourenço \& E.Lucas, Phytotaxa 373: 80. 2018.

Calyptranthes pteropoda O.Berg, Fl. bras. 14: 47. 1857.

Fig. 5b-c

Trees 5-17 m. Leaves with petiole 0.6-1 cm long; blade concolourous, elliptic or ovate, 8-20 × 3-6.3 cm, chartaceous, glabrous adaxially and with sparse, whitish indumentum abaxially; apex acuminate, base obtuse or less often cuneate or rounded; midvein sulcate adaxially and raised abaxially, secondary veins $18-26$ pairs, inconspicuous on both surfaces, marginal veins two, the inner $0.1-0.2 \mathrm{~cm}$ from the margin. Inflorescences 3-6.5 cm long, terminal, with white indumentum on the rachis, dense; branching absent (but flowers opposite); bracts lanceolate, $1-1.5 \mathrm{~cm}$ long, bracteoles not seen. Flower buds not seen, open flowers with white indumentum on hypanthium (0.4-0.5 cm long) and the attached calyptra, the latter apparently not or little apiculate. Fruits globose, 0.6-1 cm diam., not pruinose, not costate, with indumentum (especially on the hypanthial tube), crowned by the hypanthial tube. 
Examined material: mata alta, estrada da Gávea, 2.II.2017, K.S. Valdemarin \& T.B. Flores 1017 (ESA, SORO); 12.XII.2016, K.S. Valdemarin et al. 433 (ESA, SORO); estrada do Flamengo, 24.I.2017, K.S. Valdemarin et al. 791 (ESA, SORO); estrada Paraju, 24.II.1994, D.A. Folli 2223 (CVRD, RB, SORO); 9.II.1999, D.A. Folli 3346 (CVRD, RB, SORO); 28.II.1999, E. Nic Lughadha 183 (CVRD, K, SORO).

Myrcia pteropoda has been recorded in the states of ES, MG, and RJ, in seasonal and ombrophilous forests of the Atlantic domain (Santos et al. 2020). It has been collected in the mata alta forests of the VNR with flowers in December and fruits in January and February. This species can be recognised by whitish, appressed indumentum, reduced and unbranched inflorescences, and flowers with campanulate hypanthium, the latter forming a hairy, flared tube in fruit. Individuals of the study site have been identified as Calyptranthes lucida var. polyantha (O.Berg) D.Legrand in herbaria, a synonym of Myrcia neolucida; however, plants of the latter species have stout, well-developed inflorescences.

\subsection{Myrcia sp.1.}

Fig. 6c

Shrubs or trees $1.8-18 \mathrm{~m}$. Leaves with petiole 1.5-2 cm long; blade concolourous, elliptic, 9-22 × 4-12 cm, slightly coriaceous, glabrous on both surfaces; apex acute to obtuse, base cuneate to obtuse; midvein sulcate adaxially and raised abaxially, secondary veins 16-18 pairs, flat or raised adaxially and raised abaxially, marginal veins two, the inner ca. $0.3 \mathrm{~cm}$ from the margin. Inflorescences $8-11 \mathrm{~cm}$ long, axillary or terminal, with rusty indumentum on the rachis; branching opposite; bracts lanceolate, $2.5-3 \mathrm{~cm}$ long, bracteoles not seen. Flower buds globose, ca. $0.6 \mathrm{~cm}$ long, with rusty indumentum; calyx completely closed, rounded, opening as a calyptra. Fruits globose, ca. $0.6 \mathrm{~cm}$ diam., not pruinose, not costate, with sparse indumentum, crowned by the hypanthial tube.

Examined material: mata alta, aceiro Catelã - João Pedro, 10.III.2015, G.S. Siqueira \& L.F.C. Campos 1064 (CVRD, RB); beira de estrada, 23.III.1986, M. Sobral 1752 (RB); estrada municipal Canto Grande, 12.III.1972, D. Sucre 8663 (RB); mata ciliar, aceiro Catelã - João Pedro, 18.XII.2008, D.A. Folli 6262 (CVRD).

Myrcia sp.1 occurs in the mata alta forests, riparian forests, and adjacent areas within the VNR. Flowering material was collected in December and fruiting material was collected in March. Specimens of this species had been identified as Calyptranthes grandifolia in herbaria in the past, a synonym of Myrcia loranthifolia (Lourenço et al. 2020). However, Myrcia sp.1 consistently differs from the conservative concept of $M$. loranthifolia here adopted by petioles $1.5-2 \mathrm{~cm}$ (vs. ca. 0.5 $\mathrm{cm}$ in M. loranthifolia), leaf blades 9-22 × 4-12 $\mathrm{cm}$ (vs. 3.5-8 × 2-5 cm in M. loranthifolia), glabrous abaxially ( $v s$. with rusty indumentum in M. loranthifolia), base cuneate to obtuse ( $v s$. rounded in $M$. loranthifolia), secondary veins 16-18 pairs (vs. 8-12 in M. loranthifolia), marginal veins two (vs. one in M. loranthifolia), and flower buds globose with rounded apex (vs. obovoid and apiculate in $M$. loranthifolia). In addition, Myrcia sp. 1 and M. loranthifolia occur in different vegetation types in the study site.

\subsection{Myrcia sp.2.}

Fig. $5 d$

Trees 3-16 m. Leaves with petiole $0.6-1.3$ cm long; blade concolourous, elliptic to slightly obovate, $6.5-14 \times 2.5-5.5 \mathrm{~cm}$, chartaceous, glabrous adaxially and with rusty, sparsely distributed trichomes abaxially; apex acuminate, base cuneate; midvein sulcate adaxially and raised abaxially, secondary veins $12-16$ pairs, inconspicuous adaxially and usually raised abaxially, marginal veins two, the inner 0.2-0.4 $\mathrm{cm}$ from the margin. Inflorescences $3-8 \mathrm{~cm}$ long, axillary or terminal, with rusty indumentum on the rachis; branching opposite; bracts lanceolate, $1.3-1.5 \mathrm{~cm}$ long, bracteoles not seen. Flower buds obovoid, 0.2-0.4 cm long, with rusty indumentum; calyx completely closed, apiculate, opening as a calyptra. Fruits globose, $0.3-0.5 \mathrm{~cm}$ diam., not pruinose, not costate, with sparse indumentum, crowned by the hypanthial tube.

Examined material: mata alta, aceiro Calimã, 30.III.2012, J.E.Q. Faria et al. 2508 (CVRD); estrada do Flamengo, 7.IV.2006, G.Q. Freire et al. 59 (CVRD, ESA, RB); 24.I.2017, K.S. Valdemarin et al. 795 (ESA, SORO); estrada Farinha Seca, 10.XII.1986, D.A. Folli 622 (CVRD); 7.V.1987, D.A. Folli 644 (CVRD, RB); estrada Jueirana Vermelha, 25.I.2017, K.S. Valdemarin et al. 849 (ESA, SORO); estrada municipal João Pedro, 17.X.1982, I.A. Silva 352 (CVRD, RB, SP); trilha do Pequi Vinagreiro, 27.I.2017, K.S. Valdemarin et al. 896 (ESA, SORO).

Myrcia sp.2 has been collected within the VNR in the mata alta forests. Flowers have been collected in January, March, October, and December, and fruits have been collected in January and March to May. Specimens of this species had been identified as Calyptranthes glazioviana in the past, a name currently considered under the synonymy of Myrcia loranthifolia, however, 


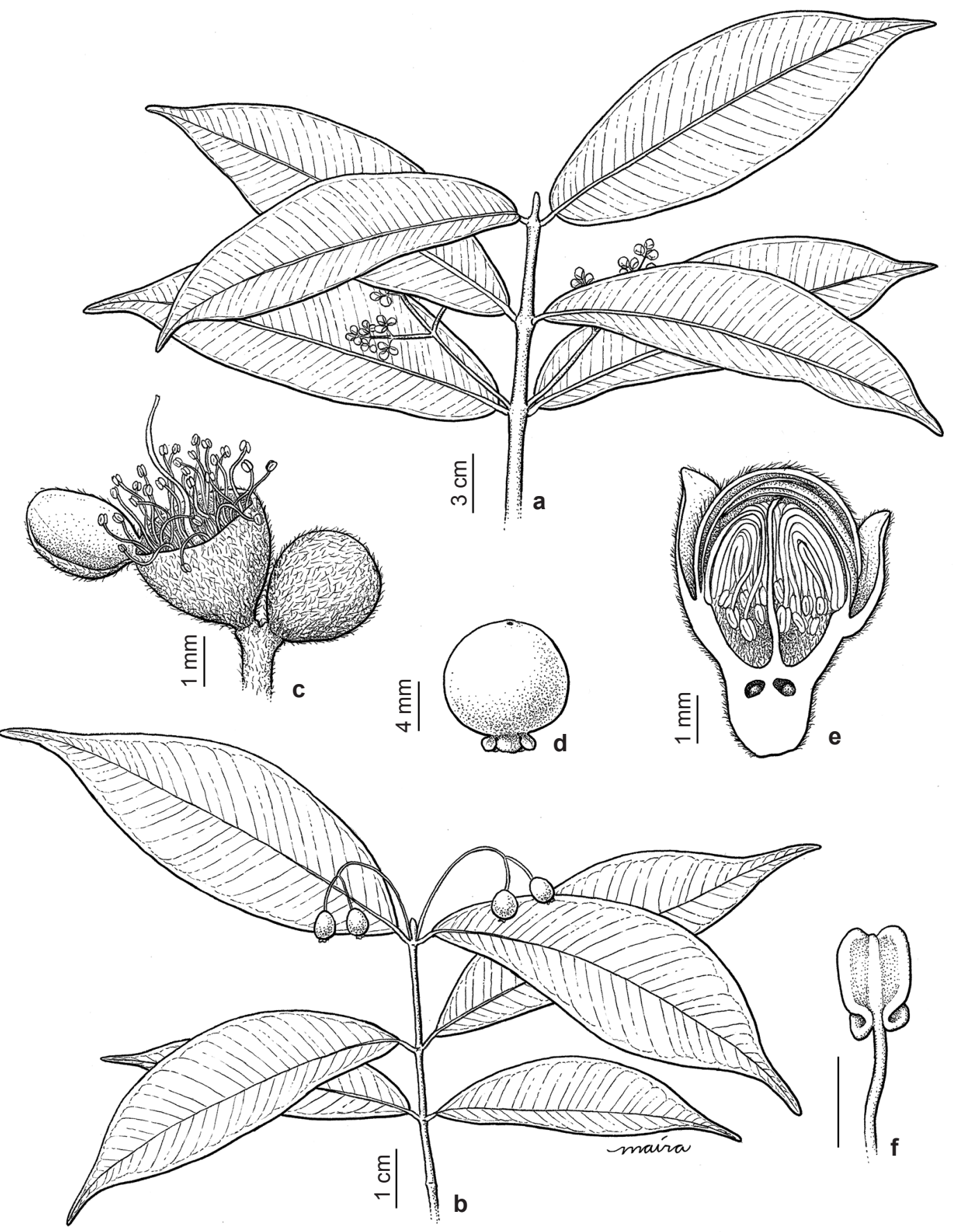

Figure 6 - a. Myrcia ferruginosa - branch. b. M. curtipendula - branch. c. Myrcia sp.1 - flower bud and open flower. d. M. freyreissiana - fruit (depicted inverted). e. M. congestiflora-longitudinal section of flower bud. f. $M$. trichantha - anther. 
Myrcia sp.2 is considerably different from the circumscription of $M$. loranthifolia here adopted. Although both species have inflorescences densely covered with rusty indumentum and apiculate flower buds in the study site, Myrcia sp.2 has considerably different leaves from those of $M$. loranthifolia (see Fig. 5 and the identification key above).

\section{Myrcia sect. Eugeniopsis (O.Berg) M.F.Santos} \& E.Lucas, Kew Bull. 73(9): 5. 2018.

Vegetative branching monopodial. Leaves with inter-secondary and tertiary veins flat; blade strongly discolourous, abaxial surface visibly contrasting with dark dots. Inflorescences with opposite branching. Flower buds obovoid; calyx basally fused in bud, opening in 4 basally torn lobes longitudinally; hypanthium longitudinally prolonged above the summit of the ovary, glabrous on the inner surface; flower disc glabrous, staminal ring glabrous, comprising up to $40 \%$ of the total disc width; anthers with symmetrical thecae, reversing curvature on dehiscence; ovary 2-locular, with two ovules per locule. Fruits globose, crowned by the hypanthial tube and the calyx, or calyx deciduous.

It is estimated that 19 species belong to Myrcia sect. Eugeniopsis, these distributed mainly in the Atlantic domain (Santos et al. 2019; Santos \& Fernandes 2020). Three of them were registered within the study site. The flowers of species of Myrcia sect. Eugeniopsis have extended hypanthium, glabrous floral disc, thin and glabrous staminal ring, and 2-locular ovary, features also present in $M$. sect. Aulomyrcia, M. sect. Calyptranthes, and M. sect. Sympodiomyrcia. However, in the former section the indumentum is dense and rufous and leaves are strongly discolourous and conspicuously dark-punctate abaxially, features exclusive of species of this section among all species of Myrcia in the VNR.

\section{Key to species of Myrcia sect. Eugeniopsis in the VNR}

1. Petioles $0.3-0.5 \mathrm{~cm}$, leaf blades $11-25 \times 4-6.5 \mathrm{~cm}$, secondary veins $30-35$ pairs

4.1. Myrcia ferruginosa

1'. Petioles $0.6-1.5 \mathrm{~cm}$, leaf blades $4-12 \times 1.5-3.5 \mathrm{~cm}$, secondary veins $12-16$ pairs 2

2. Petioles $0.6-0.8 \mathrm{~cm}$, blade apex acute or less often acuminate, secondary veins $12-14$ pairs ...... 4.2. Myrcia gaudichaudiana

2'. Petioles ca. $1.5 \mathrm{~cm}$, blade apex long-acuminate to caudate, secondary veins 14-16 pairs 4.3. Myrcia polygama

4.1. Myrcia ferruginosa Mazine, Phytotaxa 173: 98. 2014.

Marlierea silvatica (O.Berg) Kiaersk., Enum. Myrt. Bras. 51. $1893 . \quad$ Figs. 6a; 9b

Trees 6-7 m. Leaves with petiole $0.3-0.5$ $\mathrm{cm}$ long; blade strongly discolourous, elliptic, $11-25 \times 4-6.5 \mathrm{~cm}$, slightly coriaceous, glabrous adaxially and with rufous indumentum abaxially; apex acuminate, base obtuse to rounded; midvein sulcate adaxially and raised abaxially, secondary veins 30-35 pairs, inconspicuous on both surfaces, marginal vein $0.1-0.2 \mathrm{~cm}$ from the margin. Inflorescences $9-13.6 \mathrm{~cm}$ long, axillary or terminal, with rufous indumentum on the rachis; branching opposite; bracts oblong, ca. $3.5 \mathrm{~cm}$ long, bracteoles not seen. Flower buds obovoid, ca. $0.4 \mathrm{~cm}$ long, with rufous indumentum; calyx partly closed, opening in 4 regular lobes. Fruits globose, $0.8-1 \mathrm{~cm}$ diam., not pruinose, not costate, with sparse, rufous indumentum, crowned by the hypanthial tube and remnants of the calyx.

Examined material: 22.I.2007, D.A. Folli 5470 (SORO); mata ciliar, aceiro do viveiro, 15.V.1997, D.A. Folli 3006 (CVRD); aceiro Milanês, 27.III.2013, G.S. Siqueira 866 (CVRD, RB); estrada Peroba-osso, 2.III.2006, D.A. Folli 5200 (CVRD); várzea, estrada Oiticica, km 1,8, 10.II.1999, E.M. Nic Lughadha et al. 187 (RB, SORO).

Myrcia ferruginosa can be found from MG to SC states, in the Atlantic rainforest (Santos et al. 2020); the occurrence of this species in ES state, previously recorded as doubtful in the Flora do Brasil database, is here confirmed. It was collected within the study site in riverine and flooded vegetation with flowers in February and March and fruits in March and May. This species is characterised by shorter petioles and larger leaf blades with more pairs of lateral veins when compared to other taxa of Myrcia sect. Eugeniopsis in the VNR. 
4.2. Myrcia gaudichaudiana (O.Berg) M.F.Santos, Kew Bull. 74(58): 3. 2019. Marlierea gaudichaudiana (O.Berg) Loefgr. \& Everett, Syst. Analyt. S. Paulo 219. 1919.

Trees ca. $8 \mathrm{~m}$. Leaves with petiole $0.6-0.8$ $\mathrm{cm}$ long; blade strongly discolourous, elliptic, $4-6.7 \times 2.5-3.4 \mathrm{~cm}$, slightly coriaceous, glabrous on both surfaces; apex acute or less often acuminate, base obtuse; midvein sulcate adaxially and raised abaxially, secondary veins $12-14$ pairs, inconspicuous on both surfaces, marginal vein ca. $0.1 \mathrm{~cm}$ from the margin. Inflorescences 5-9 cm long, axillary or terminal, with rufous indumentum on the rachis; branching opposite; bracts not seen, bracteoles not seen. Flower buds obovoid, ca. $0.3 \mathrm{~cm}$ long, with rufous indumentum; calyx partly closed, opening in 4 regular lobes. Fruits not seen.

Examined material: mata alta, trilha da Perobaamarela, 30.X.1991, D.A. Folli 1466 (CVRD, RB).

Myrcia gaudichaudiana is endemic to the Atlantic forest of ES state (Santos et al. 2020). In the VNR it was registered in the mata alta forests; flowering material was collected in October. Discolourous leaves with usually acute apex and long petioles are distinguishing features of this species.

4.3. Myrcia polygama (O.Berg) M.F.Santos, Kew Bull. 74(58): 6. 2019.

Marlierea polygama (O.Berg) D.Legrand, Comun. Bot. Mus. Hist. Nat. Montevideo 3(40): 30. 1962.

Fig. 9a,d

Shrubs or trees 4-11 m. Leaves with petiole ca. $1.5 \mathrm{~cm}$ long; blade strongly discolourous, elliptic, ovate, or lanceolate, 6-12 × 1.5-3.5 $\mathrm{cm}$, slightly coriaceous, glabrous or with rufous trichomes distributed along the midvein adaxially and with rufous sparse indumentum abaxially; apex long-acuminate to caudate, base cuneate to attenuate; midvein sulcate adaxially and raised abaxially, secondary veins 14-16 pairs, inconspicuous adaxially and raised abaxially, marginal vein ca. $0.1 \mathrm{~cm}$ from the margin. Inflorescences 4-6 cm long, axillary, with rufous indumentum on the rachis, sparse; branching opposite; bracts oblong, 2.5-3 cm long, bracteoles not seen. Flower buds obovoid, ca. $0.2 \mathrm{~cm}$ long, with dense, rufous indumentum; calyx partly closed, opening in 4 regular lobes. Fruits globose, ca. $1 \mathrm{~cm}$ diam., not pruinose, not costate, glabrous, crowned by the hypanthial tube and remnants of the calyx.

Examined material: 21.X.2008, D.A. Folli 6439 (SORO); mata alta, estrada 143, talhão 403, 3.X.1972, A.M. Lino 122 (RB); estrada X1, talhão 506, 3.X.1972, A.M. Lino 125 (RB); trilha do Pequi Vinagreiro, 18.III.2005, D.A. Folli 5038 (CVRD); mata ciliar, estrada da Gávea, 15.IX.2009, D.A. Folli 4932 (CVRD).

Myrcia polygama occurs from BA to RJ states, in the Atlantic domain (Santos et al. 2020). It was collected in the mata alta forests and riparian vegetation inside the study site. Flowering material was collected in September and October and fruiting material was collected in March. Remarkable features of this species are long petioles, leaf blades with long-acuminate to caudate apex, and rufous inflorescences.

5. Myrcia sect. Gomidesia (O.Berg) B.S.Amorim \& E.Lucas, Kew Bull. 73(9): 6. 2018.

Vegetative branching monopodial. Leaves with inter-secondary and tertiary veins usually flat; blade not strongly discolourous, abaxial surface not visibly contrasting with dark dots. Inflorescences with opposite branching. Flower buds globose or obovoid; calyx free in bud, opening in 5 intact lobes; hypanthium slightly prolonged longitudinally above the summit of the ovary, pubescent on the inner surface; flower disc pubescent, staminal ring pubescent, comprising up to $40 \%$ of the total disc width; anthers with asymmetrical thecae, maintaining curvature at dehiscence; ovary 2-3(-5)-locular, with two ovules per locule. Fruits globose or subconic, crowned by the hypanthial tube and the calyx.

Myrcia sect. Gomidesia comprises about 57 species, distributed mainly in the Alantic and Cerrado domains (Lucas et al. 2018); eight of them occur in the VNR. It is a diverse section is morphological features in the study site, varying considerably in leaf, inflorescence, flower, and fruits traits. All species of Myrcia sect. Gomidesia in the VNR have flowers with slightly extended hypanthium, pubescent flower disc, and anthers with asymmetrical thecae, maintaining curvature at dehiscence, a combination of features unique of this section. 


\section{Key to species of Myrcia sect. Gomidesia in the VNR}

1. Inflorescences undeveloped, rachis without lateral branches .................................................. 2

1'. Inflorescences developed, rachis with lateral branches ......................................................... 6

2. Flower buds obovoid; fruits subconic

5.8. Myrcia vittoriana

2'. Flower buds globose; fruits globose

3. Calyx lobes acute, apiculate

5.2. Myrcia congestiflora

3'. Calyx lobes obtuse to rounded, not apiculate.

4. Leaf blades with sparse indumentum adaxially, inner marginal vein $0.3-0.7 \mathrm{~cm}$ distant from margin; flower buds $0.4-0.5 \mathrm{~cm}$; fruits $0.9-1.2 \mathrm{~cm}$. 5.6. Myrcia springiana

4'. Leaf blades glabrous or indumentum concentrated only along the midvein adaxially, inner marginal vein $0.05-0.2 \mathrm{~cm}$ distant from margin, flower buds $0.2-0.3 \mathrm{~cm}$; fruits $0.3-0.8 \mathrm{~cm}$.

5. Leaf blades with attenuate base; rachis with dense indumentum; calyx lobes ca. 0.3 $\mathrm{cm}$.

5.1. Myrcia cerqueiria

5'. Leaf blades with cuneate base; rachis with sparse indumentum; calyx lobes ca. 0.1 $\mathrm{cm}$. 5.3. Myrcia curtipendula

6. Leaf blades with obtuse or rounded apex

6'. Leaf blades with acute, short-acuminate, or acuminate apex...................... 8

7. Petioles $0.2-0.4 \mathrm{~cm}$, leaf blades with obtuse or rounded base, secondary veins 6-8 pairs; bracteoles ca. $0.2 \mathrm{~cm}$; flower buds globose; fruits smooth

5.5. Myrcia palustris

7'. Petioles $0.4-0.7 \mathrm{~cm}$, leaf blades with attenuate base, secondary veins 8-10 pairs; bracteoles $0.3-0.5 \mathrm{~cm}$; flower buds obovoid; fruits slightly costate..... 5.7. Myrcia trichantha

8. Flower buds obovoid; fruits subconic 5.8. Myrcia vittoriana

8'. Flower buds globose; fruits globose. 9

9. Leaf blades with acute or short-acuminate apex, secondary veins 6-12 pairs; inflorescence rachises glabrous or with sparse indumentum 5.4. Myrcia freyreissiana

9'. Leaf blades with acuminate apex, secondary veins 10-30 pairs; inflorescence rachises with dense indumentum. 10

10. Shrubs or trees $1.5-3 \mathrm{~m}$; leaf blades with inner marginal vein $0.05-0.2 \mathrm{~cm}$ from margin; bracteoles ca. $0.4 \mathrm{~cm}$; flower buds $0.2-0.3 \mathrm{~cm}$; fruits $0.3-0.8 \mathrm{~cm}$.

5.1. Myrcia cerqueiria

10'. Trees 5-21 m; leaf blades with inner marginal vein $0.3-0.7$ $\mathrm{cm}$ from margin; bracteoles ca. $0.3 \mathrm{~cm}$; flower buds $0.4-0.5$ $\mathrm{cm}$; fruits $0.9-1.2 \mathrm{~cm}$. 5.6. Myrcia springiana

5.1. Myrcia cerqueiria (Nied.) E.Lucas \& Sobral, Phytotaxa 8: 54. 2010.

Gomidesia cerqueiria Nied., Nat. Pflanzenfam. 3(7): 78. 1893.

Fig. 7a-c

Shrubs or trees $1.5-3 \mathrm{~m}$. Leaves with petiole $0.3-0.7 \mathrm{~cm}$ long; blade discolourous, elliptic to narrowly elliptic, $4.5-21 \times 1.7-6.3 \mathrm{~cm}$, chartaceous, glabrous or with yellow indumentum mainly along the midvein adaxially and with yellow indumentum abaxially; apex acuminate, base attenuate; midvein sulcate adaxially and raised abaxially, secondary veins $10-30$ pairs, flat or raised on both surfaces, marginal veins two, the inner $0.05-0.2 \mathrm{~cm}$ from the margin. Inflorescences 1-4 cm long, axillary or terminal, with whitish or yellowish indumentum on the rachis, dense; branching opposite; bracts not seen, bracteoles lanceolate, ca. $0.4 \mathrm{~cm}$ long. Flower buds globose, $0.2-0.3 \mathrm{~cm}$ long, indumentum grey to yellow, dense; calyx open, with 5 free lobes, these obtuse to rounded, ca. $0.3 \mathrm{~cm}$ long. Fruits globose, $0.3-0.8 \mathrm{~cm}$ diam., not pruinose, not costate, with indumentum, crowned by the hypanthial tube and the calyx. 

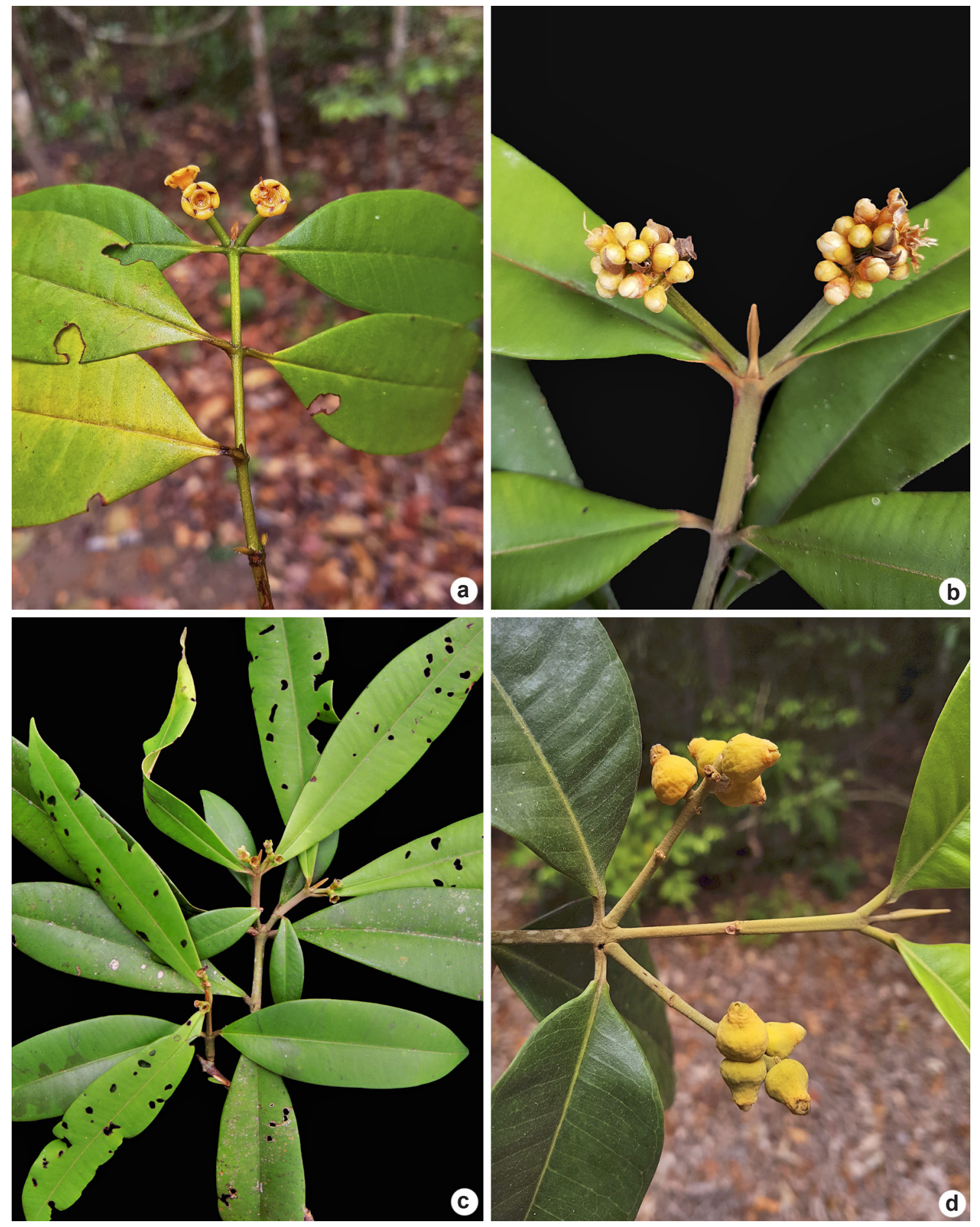

Figure 7 - a-d. Myrcia sect. Gomidesia - a-c. M. cerqueiria; d. M. vittoriana. 
Examined material: mata alta, aceiro Aracruz, 30.III.2012, J.E.Q. Faria et al. 2504 (CVRD); aceiro Calimã, 7.V.1997, D.A. Folli 3001 (CVRD); estrada da Gávea, 18.VI.2002, D.A. Folli 4271 (CVRD); 1.XII.2006, E.J. Lucas et al. 912 (CVRD, ESA, RB, SORO); estrada do Flamengo, 1.II.1999, V.F. Mansano 40 (CVRD); 24.I.2017, K.S. Valdemarin et al. 810 (ESA, SORO); estrada Oiticica, 9.V.2009, P.J.M. Mass et al. 9830 (CVRD); estrada Paraju, 9.II.1999, E. Nic Lughadha 182 (CVRD, RB, SP); 17.III.1993, E. Nic Lughadha 155 (CVRD); próximo à porteira Bragato, 7.VI.2007, M.C. Souza et al. 543 (CVRD, RB); trilha da Peroba-amarela, 23.I.2017, K.S. Valdemarin et al. 775 (ESA, SORO); 23.I.2017, K.S. Valdemarin et al. 774 (ESA, SORO); trilha do Pequi.Vinagreiro, 27.I.2017, K.S. Valdemarin et al. 897 (ESA, SORO); trilha próxima à antiga torre, 22.III.2019, K.S. Valdemarin et al. 1223 (ESA); 17.II.1993, E. Nic Lughadha 154 (CVRD).

Myrcia cerqueiria is known from collections made from BA to RJ states, in ombrophilous forests of the Atlantic domain (Santos et al. 2020). In the study site it has been collected within the mata alta forests. Flowers were collected in January and February and fruits were collected in March, May, and June. This species is characterised by long leaves with acuminate apex and short inflorecences.

\subsection{Myrcia congestiflora Caliari \& V.C.Souza,} Phytotaxa 267: 202. 2016.

Fig. 6e

Trees ca. $5 \mathrm{~m}$. Leaves with petiole $0.4-0.5$ cm long; blade slightly discolourous, elliptic to oblong, 12-20 × 4.6-6.6 cm, chartaceous, with yellow, dense indumentum concentrated along the midvein and lateral veins on both surfaces; apex acuminate, base cuneate to obtuse; midvein sulcate adaxially and raised abaxially, secondary veins $10-12$ pairs, inconspicuous adaxially and raised abaxially, marginal veins two, the inner ca. $0.5 \mathrm{~cm}$ from the margin. Inflorescences $2.5-5 \mathrm{~cm}$ long, terminal, indumentum on the rachis yellow, dense; branching absent (flowers opposite); bracts not seen, bracteoles not seen. Flower buds globose, $0.4-0.5 \mathrm{~cm}$ long, indumentum yellow, dense; calyx open, with 5 free lobes, these acute and apiculate, ca. 0.3 $\mathrm{cm}$ long. Fruits globose, $1-1.4 \mathrm{~cm}$ diam., not pruinose, not costate, with moderate or dense indumentum, crowned by the hypanthial tube and the calyx.

Examined material: mata alta, estrada Regência, 22.I.2015, D.A. Folli 7323 (CVRD).

Additional material: BRAZIL. RIO DE JANEIRO: Paraty, fazenda São Roque, 2.VIII.1988, M.C. Marques
66 (RB). SÃO PAULO: Caraguatatuba, Parque Estadual da Serra do Mar, núcleo Caraguatatuba, nova trilha dos tropeiros, 17.VII.2000, F.O Souza et al. 20 (SPF).

Myrcia congestiflora is endemic to the Atlantic forest in RJ and SP states (Santos et al. 2020); it is reported in ES state for the first time. It has been collected within the study site in the mata alta forests, where flowering material was collected in January and fruiting material was collected in May. This species is characterised by large, acuminate leaves, short inflorescences with clustered flowers, and acute or apiculate calyx lobes.

5.3. Myrcia curtipendula NicLugh., Kew Bull. 65: 21.2010.

Fig. $6 \mathrm{~b}$

Treelets 2-3 m. Leaves with petiole $0.3-$ $0.4 \mathrm{~cm}$ long; blade slightly discolourous, elliptic to obovate, $5-10 \times 1.5-2.5 \mathrm{~cm}$, chartaceous, glabrous adaxially and with yellow, sparse indumentum concentrated along the midvein abaxially; apex acuminate, base cuneate; midvein sulcate adaxially and raised abaxially, secondary veins 14-16 pairs, inconspicuous on both surfaces, marginal veins two, the inner ca. $0.1 \mathrm{~cm}$ from the margin. Inflorescences $2-4$ $\mathrm{cm}$ long, terminal, indumentum on the rachis yellow, sparse; branching absent (flowers opposite); bracts not seen, bracteoles not seen. Flower buds globose, ca. $0.3 \mathrm{~cm}$ long, indumentum yellow; calyx open, with 5 free lobes, these rounded, ca. $0.1 \mathrm{~cm}$ long. Fruits globose, ca. $0.4 \mathrm{~cm}$ diam., not pruinose, not costate, with sparse indumenum, crowned by the hypanthial tube and the calyx.

Examined material: mata alta, estrada do Flamengo, 13.IV.2004, D.A. Folli 4818 (CVRD).

Additional material: BRAZIL. ESPÍRITO SANTO: Itarana, Alto Jatibocas, 14.II.1999, E.M. Nic Lughadha et al. 202 (RB). Santa Teresa, Estação Biológica de São Lourenço, 13.II.1999, E.M. Nic Lughadha et al. 194 (RB); 13.II.1999, E.M. Nic Lughadha et al. 195 (RB, SP); limite norte da Estação Biológica de Nova Lombardia, 13.II.1999, E.M. Nic Lughadha et al. 198 (RB).

Myrcia curtipendula is known from specimens collected in ES state only, in ombrophilous forests of the Atlantic domain (Santos et al. 2020). In the VNR it was registered in the mata alta forests. Flowering material was collected in February and fruiting material was collected in April. This species is characterised by delicate branches bearing long-acuminate leaves and pauciflorous inflorescences. 
5.4. Myrcia freyreissiana (O.Berg) Kiaersk., Enum. Myrt. Bras. 102. 1893.

Myrcia brasiliensis Kiaersk., Enum. Myrt. Bras. 102. 1893.

Gomidesia freyreissiana O.Berg, Fl. bras. 14: 19. 1857.

Gomidesia schaueriana O.Berg, Fl. bras. 14: 18. 1857.

Fig. 6d

Treelets or trees $2-10 \mathrm{~m}$. Leaves with petiole $0.5-1 \mathrm{~cm}$ long; blade discolourous, elliptic to obovate, $3.5-13.5 \times 2-6 \mathrm{~cm}$, chartaceous or coriaceous, glabrous or with yellow, sparse indumentum on both surfaces; apex acute to shortacuminate, base attenuate, cuneate, or obtuse; midvein sulcate adaxially and raised abaxially, secondary veins 6-12 pairs, inconspicuous adaxially and raised abaxially, marginal veins two, the inner $0.1-0.5 \mathrm{~cm}$ from the margin. Inflorescences $3.5-12 \mathrm{~cm}$ long, axillary or terminal, rachis glabrous or with yellow, sparse indumentum; branching opposite; bracts oblanceolate, ca. $1.5 \mathrm{~cm}$ long, bracteoles not seen. Flower buds globose, $0.1-0.5 \mathrm{~cm}$ long, indumentum yellow, sparse; calyx open, with 5 free lobes, these obtuse to rounded, $0.1-0.2 \mathrm{~cm}$ long. Fruits globose, $0.5-1 \mathrm{~cm}$ diam., not pruinose, not costate, with sparse indumentum, crowned by the hypanthial tube and the calyx.

Examined material: mata ciliar, aceiro do Viveiro, 26.III.2007, D.A. Folli 5522 (CVRD); estrada Bomba d'água, 30.VI.1993, D.A. Folli 1926 (CVRD); estrada Farinha Seca, 29.XI.1982, I.A. Silva 365 (CVRD); estrada Oiticica, 14.XII.1982, I.A. Silva 373 (CVRD, RB); Mussununga, estrada da Gávea, 22.II.1999, E. Nic Lughadha 186 (CVRD); várzea periodicamente inundada, estrada Gonçalo Alves, 18.II.2011, G.S. Siqueira 606 (CVRD); 20.IX.2001, D.A. Folli 4063 (CVRD); 30.X.2012, V.G. Staggemeier et al. 908 (CVRD).

Myrcia freyreissiana is distributed from BA to RS states, in ombrophilous forests and restingas of the Atlantic domain (Santos et al. 2020). It has been collected in the VNR in flooded areas, mussununga forests, and riparian vegetation. Flowering material was collected in October and November and fruiting material was collected in February, March, June and September. Besides the features presented in the identification key, Myrcia freyreissiana is characterised by many-flowered inflorescences with a long peduncle. It resembles Myrcia trichantha, but it has smooth fruits (vs. slightly costate in $M$. trichantha). Santos et al. (2020) cites "Myrcia brasiliensis" as an accepted name of this taxon, but according to Art. 11.4 of the International Code of Nomenclature for algae, fungi, and plants, the correct name of a species must be composed of the currently accepted genus and earliest legitimate epithet available for combination (Turland et al. 2018). Hence, in this case "Myrcia freyreissiana" must be adopted.

5.5. Myrcia palustris DC., Prodr. 3: 246. 1828. Gomidesia palustris (DC.) Kausel, Lilloa 32: 348. 1966.

Shrubs or treelets 2-5 m. Leaves with petiole $0.2-0.4 \mathrm{~cm}$ long; blade discolourous, elliptic, $1.5-4.5 \times 1-3 \mathrm{~cm}$, slightly coriaceous, with yellow, sparse indumentum on both surfaces; apex obtuse to rounded, base obtuse to rounded; midvein flat to slightly sulcate adaxially and raised abaxially, secondary veins 6-8 pairs, inconspicuous on both surfaces, marginal vein $0.1-0.15 \mathrm{~cm}$ from the margin. Inflorescences 3-8 cm long, axillary or terminal, with yellowish indumentum on the rachis, sparse to dense, branching opposite; bracts not seen, bracteoles lanceolate, ca. $0.2 \mathrm{~cm}$ long. Flower buds globose, $0.2-0.3 \mathrm{~cm}$ long, indumentum yellow; calyx open, with 5 free lobes, these acute to obtuse, $0.1-0.15 \mathrm{~cm}$ long. Fruits globose, $0.3-0.5$ $\mathrm{cm}$ diam., not pruinose, not costate, with sparse to dense indumentum, crowned by the hypanthial tube and the calyx.

Examined material: campo nativo, estrada Jueirana Vermelha, 20.I.1999, D.A. Folli 3334 (CVRD, RB); mata ciliar, estrada Canto Grande, 27.I.1992, D.A. Folli 1568 (CVRD, RB); estrada Paraju, 14.XII.2012, G.S. Siqueira 845 (CVRD, RB); várzea periodicamente inundada, aceiro da estrada Paraju, 17.IV.2001, D.A. Folli 3886 (CVRD, RB); estrada da Gávea, 20.VI.2000, D.A. Folli 3640 (CVRD); várzea permanentemente inundada, estrada da Gávea, 20.VI.2000, D.A. Folli 3641 (CVRD).

In Brazil Myrcia palustris is distributed from BA to RS states, in the Atlantic and Caatinga domains (Amorim 2017; Santos et al. 2020). In the VNR it was registered in the campo nativo, flooded areas, and riparian vegetation. Flowering material was collected in December and fruiting material was collected in April and May. This species is characterised by small, orbicular leaves and manyflowered inflorescences.

5.6. Myrcia springiana (O.Berg) Kiaersk., Enum. Myrt. Bras. 102. 1893.

Gomidesia springiana O.Berg, Fl. bras. 14: 13. 1857.

Trees 5-21 m. Leaves with petiole $0.4-0.8 \mathrm{~cm}$ long; blade slightly discolourous, elliptic, 3.5-21 $\times 1.3-4.8 \mathrm{~cm}$, chartaceous, with yellow, sparse indumentum on both surfaces; apex acuminate, 
base attenuate; midvein sulcate adaxially and raised abaxially, secondary veins $12-16$ pairs, inconspicuous adaxially and raised abaxially, marginal veins two, the inner $0.3-0.7 \mathrm{~cm}$ from the margin. Inflorescences $1.5-9 \mathrm{~cm}$ long, axillary or terminal, with yellowish indumentum on the rachis, sparse to dense, branching opposite; bracts not seen, bracteoles lanceolate, ca. $0.3 \mathrm{~cm}$ long. Flower buds globose, $0.4-0.5 \mathrm{~cm}$ long, indumentum yellow, dense; calyx open, with 5 free lobes, these obtuse to rounded, ca. $0.15 \mathrm{~cm}$ long. Fruits globose, $0.9-1.2 \mathrm{~cm}$ diam., not pruinose, not costate, with sparse to dense indumentum, crowned by the hypanthial tube and the calyx.

Examined material: mata alta, aceiro Catelã - João Pedro, 27.IX.2004, D.A. Folli 4944 (CVRD); estrada Bicuíba, 17.IX.2008, G.S. Siqueira 436 (CVRD); 22.III.2008, G.S. Siqueira 397 (CVRD); trilha do Pequi Vinagreiro, 30.I.2002, D.A. Folli 4177 (CVRD); 5.II.1972, J. Spada 4 (RB).

Myrcia springiana has been registered from $\mathrm{BA}$ to ES and MG states, in the Atlantic domain (Santos et al. 2020). This species has been collected in the mata alta forests within the study site; flowers were collected in February and March and fruits were collected in January and September. It can be recognised by leaves with inner marginal vein $0.3-0.7 \mathrm{~cm}$ distant from margin, flower buds $0.4-0.5 \mathrm{~cm}$, and fruits $0.9-1.2 \mathrm{~cm}$.

\subsection{Myrcia trichantha (Warwa) Sobral, Phytotaxa} 302: 199. 2017.

Myrcia ilheosensis Kiaersk., Enum. Myrt. Bras. 109. 1893.

Gomidesia fenzliana O.Berg, Fl. bras. 14: 20. 1857.

Fig. $6 f$

Treelets or trees $1.5-5 \mathrm{~m}$. Leaves with petiole $0.4-0.7 \mathrm{~cm}$ long; blade discolourous, elliptic to obovate, $2.5-9 \times 1.6-5 \mathrm{~cm}$, coriaceous, with grey, sparse to dense indumentum on both surfaces; apex rounded, base attenuate; midvein slightly sulcate adaxially and raised abaxially, secondary veins $8-10$ pairs, inconspicuous adaxially and flat to raised abaxially, marginal veins two, the inner $0.1-0.3 \mathrm{~cm}$ from the margin. Inflorescences $5-16 \mathrm{~cm}$ long, axillary or terminal, with greyish or yellowish indumentum on the rachis, sparse to dense; branching opposite; bracts lanceolate, $0.8-1.3 \mathrm{~cm}$ long, bracteoles lanceolate, $0.3-0.5$ $\mathrm{cm}$ long. Flower buds obovoid, $0.25-0.3 \mathrm{~cm}$ long, indumentum grey to yellow, dense; calyx open, with 5 free lobes, these acute to obtuse, $0.1-0.15$ $\mathrm{cm}$ long. Fruits globose, $0.3-0.7 \mathrm{~cm}$ diam., not pruinose, slightly costate, with sparse to dense indumentum, crowned by the hypanthial tube and the calyx.

Examined material: campo nativo, estrada da Gávea, 8.II.1999, E. Nic Lughadha 173 (CVRD, RB, SP); estrada Paraju, 6.I.1987, D.A. Folli 625 (CVRD, RB); 19.IV.1989, D.A. Folli 902 (CVRD, RB); 31.I.1990, G.L. Farias 352 (CVRD, RB); Mussununga, estrada municipal, 22.XI.2005, D.A. Folli 5136 (CVRD); estrada Paraju, 11.I.2007, D.A. Folli 5442 (CVRD).

Myrcia trichantha is distributed from SE to RS states, in ombrophilous forests and restingas of the Atlantic domain (Santos et al. 2020). In the VNR it was collected in the campo nativo and mussununga forests. Flowering material was collected in November, January and February, and fruiting material was collected in January and April. It may be confused with Myrcia freyreissiana, differing in leaf blades with obtuse or rounded apex (vs. acute or short-acuminate in the latter) and slightly costate fruits (vs. smooth in the latter). Santos et al. (2020) erroneously considered "Myrcia ilheosensis" an accepted name of this species, but the name published by Sobral (2007) has priority over the former (see the notes under M. freyreissiana). The synonym Myrcia ilheosensis and its basionym Gomidesia fenzliana are often applied to herbarium material of this species.

5.8. Myrcia vittoriana Kiaersk., Enum. Myrt. Bras. 102. 1893.

Gomidesia martiana O.Berg, Fl. bras. 14: 12. 1857.

Fig. $7 \mathrm{~d}$

Shrubs to trees 3-6 m. Leaves with petiole $0.5-1 \mathrm{~cm}$ long; blade slightly discolourous, elliptic or ovate, $12-19 \times 4-6.5 \mathrm{~cm}$, chartaceous, glabrous or with yellow, sparse indumentum adaxially and with yellow indumentum concentrated along the midvein and secondary veins abaxially; apex acuminate, base attenuate to rounded; midvein slightly sulcate adaxially and raised abaxially, secondary veins $12-16$ pairs, flat or raised adaxially and raised abaxially, marginal veins two, the inner $0.1-0.4 \mathrm{~cm}$ from the margin. Inflorescences $3.5-10 \mathrm{~cm}$ long, axillary or terminal, with yellowish indumentum on the rachis, dense; branching opposite; bracts lanceolate, ca. $0.8 \mathrm{~cm}$ long, bracteoles lanceolate, $0.3-0.5 \mathrm{~cm}$ long. Flower buds obovoid, $0.4-0.5 \mathrm{~cm}$ long, indumentum yellow, dense; calyx open, with 5 free lobes, these obtuse to rounded, $0.15-0.2 \mathrm{~cm}$ long. Fruits subconic, $0.5-1$ $\mathrm{cm}$ long, not pruinose, striate, with indumentum, crowned by the hypanthial tube and the calyx. 
Examined material: mata alta, estrada do Flamengo, 1.III.1991, D.A. Folli 1302 (CVRD); estrada Jacarandá - Caviúna, 1.II.2017, K.S. Valdemarin \& T.B. Flores 1002 (ESA, SORO); estrada Paraju, 31.I.2017, K.S. Valdemarin \& T.B. Flores 945 (ESA, SORO); Mussununga, estrada Boleira, 30.X.2003, D.A. Folli 4656 (CVRD); estrada do Flamengo, 22.I.1991, D.A. Folli 1268 (CVRD); 27.XI.1989, G.L. Farias 344 (CVRD, RB); estrada Jacarandá, 19.XI.2004, G.S. Siqueira 135 (CVRD).

Myrcia vittoriana is known from collections made from PE to RJ states, ombrophilous forests and restingas of the Atlantic domain (Santos et al. 2020). It has been collected in the VNR in the mata alta and mussununga forests. Flowering individuals were collected in October and November and fruiting individuals were collected from January to March. This species is easily recognised with basis on yellow, farinaceous indumentum covering inflorescences, flowers, and the subconic fruits.

\section{Myrcia sect. Myrcia.}

Vegetative branching monopodial. Leaves with inter-secondary and tertiary veins usually flat; blade not strongly discolourous, abaxial surface not visibly contrasting with dark dots. Inflorescences with alternate, opposite, or subopposite branching. Flower buds globose, calyx free in bud, opening in 5 intact lobes; hypanthium not longitudinally prolonged above the summit of the ovary, pubescent on the inner surface; flower disc pubescent, staminal ring pubescent, comprising at least $60 \%$ of the total disc width; anthers with symmetrical thecae, reversing curvature at dehiscence; ovary 2-locular, with two ovules per locule. Fruits ellipsoid or globose, crowned by the calyx.

Five of the 98 species that belong to Myrcia sect. Myrcia occur in the study site, a section distributed throughout the geographical range of the genus (Santos 2017). Species of Myrcia sect. Myrcia in the study site have flowers with unextended hypanthium, free calyx, pubescent flower disc, and anthers reversing curvature at dehiscence. Ellipsoid fruits, pointed out by Lucas et al. (2018) as important in species of this section, is found only in two species in the VNR.

\section{Key to species of Myrcia sect. Myrcia in the VNR}

1. Indumentum rusty 2

1 '. Indumentum yellow to brown

2. Leaf blades with $12-14$ pairs of lateral veins, these raised adaxially

2'. Leaf blades with 8-10 pairs of lateral veins, these sulcate adaxially 6.1. Myrcia bergiana

3. Leaf blades with lateral veins inconspicuous adaxially, fruits globose .....6.3. Myrcia ovata

3'. Leaf blades with lateral veins raised adaxially, fruits ellipsoid 2. Myrcia isaiana

4. Petioles $0.2-0.5 \mathrm{~cm}$, leaf blades with apex acute to acuminte, marginal veins $0.1-0.2 \mathrm{~cm}$ distant from the blade margins . 6.4. Myrcia splendens

4'. Petioles $0.6-0.8 \mathrm{~cm}$, leaf blades with apex long-acuminate to caudate, marginal veins $0.2-0.4 \mathrm{~cm}$ distant from the blade margins .... 6.5. Myrcia sp.3

6.1. Myrcia bergiana O.Berg, Fl. bras. 14: 194. 1857.

Trees 7-22 m. Leaves with petiole $0.7-1.5$ cm long; blade discolourous, elliptic, 4-13 $\times$ $2.3-5.8 \mathrm{~cm}$, coriaceous to chartaceous, with rusty indumentum concentrated along the midvein adaxially and with sparse to dense, rusty indumentum abaxially; apex acuminate to longacuminate, base cuneate, obtuse, or rounded; midvein raised or slightly sulcate adaxially and raised abaxially, secondary veins $12-14$ pairs, raised on both surfaces, marginal veins two, the inner $0.15-0.4 \mathrm{~cm}$ from the margin. Inflorescences 5-15 cm long, axillary or terminal, with rusty indumentum on the rachis; branching opposite or sub-opposite; bracts not seen, bracteoles not seen. Flower buds globose, ca. $0.25 \mathrm{~cm}$ long, indumentum rusty; calyx open, with 5 free lobes, these obtuse, $0.1-0.15 \mathrm{~cm}$ long. Fruits globose, $0.6-0.9 \mathrm{~cm}$ diam., not pruinose, not costate, with sparse indumentum, crowned by the calyx.

Examined material: mata alta, estrada Caingá, 26.I.2004, D.A. Folli 4745 (CVRD); Mussununga, estrada Paraju, 26.IV.2005, D.A. Folli 5056 (CVRD); 2.XII.2006, E.J. Lucas et al. 955 (ESA, RB).

Myrcia bergiana occurs from RN to ES states, in the Caatinga and Atlantic domains (Santos et al. 2020). It was collected within the study site in the 
mata alta and mussununga forests with flowers in January and with fruits in April. It resembles Myrcia isaiana in rusty indumentum, being distinguished by leaf blades not bullate (vs. bullate in the latter), with lateral veins raised adaxially ( $v s$. sulcate in the latter).

6.2. Myrcia isaiana G.M.Barroso \& Peixoto, Acta Bot. Bras. 4(2): 8. 1990.

Fig. 8a

Trees 14-18 m. Leaves with petiole $0.5-1$ cm long; blade discolourous, elliptic, 6.5-15 $\times 2.5-9 \mathrm{~cm}$, coriaceous, glabrous adaxially or with rusty indumentum on both surfaces; apex short-acuminate to long-acuminate, base obtuse to rounded; midvein sulcate adaxially and raised abaxially surface, secondary veins $8-10$ pairs, sulcate adaxially and raised abaxially, marginal veins two, the inner $0.3-0.5 \mathrm{~cm}$ from the margin. Inflorescences 1.7-12 cm long, axillary or terminal, with rusty indumentum on the rachis; branching opposite; bracts elliptic, ca. $1.25 \mathrm{~cm}$ long, bracteoles rounded to lanceolate, 0.2-0.4 $\mathrm{cm}$ long. Flower buds globose, 0.2-0.4 cm long, indumentum rusty; calyx open, with 5 free lobes, these obtuse to rounded, $0.15-0.2 \mathrm{~cm}$ long. Fruits globose, $0.5-1 \mathrm{~cm}$ diam., not pruinose, not costate, with sparse indumentum, crowned by the calyx.

Examined material: mata alta, aceiro com LASA, 14.XII.1989, G.L. Farias 349 (CVRD, RB); estrada da Gávea, 25.II.1980, I.A. Silva 150 (CVRD, RB); 8.VI.1994, D.A. Folli 2326 (CVRD); estrada Orelhade-onça, 3.X.1972, A.M. Lino 120 (RB); 15.IX.1978, I.A. Silva 21 (CVRD, RB).

Myrcia isaiana can be found from PE to $\mathrm{SC}$, in ombrophilous forests and restingas of the Atlantic domain (Santos et al. 2020). This species was collected in the mata alta forests within the VNR; flowering material was collected in February, September, and October, and fruiting material was collected in June and December. It is characterised by coriaceous, bullate leaf blades with secondary veins sulcate adaxially and inflorescences with well-developed bracts and bracteoles.

6.3. Myrcia ovata Cambess., Fl. Bras. Merid. 2: 319. 1828 .

Fig. 8d

Treelets or trees 2-24 m. Leaves with petiole $0.5-1.5 \mathrm{~cm}$ long; blade slightly discolourous, ovate or elliptic, 2-16 × 4-6 cm, coriaceous, glabrous or with sparse, yellow indumentum concentrated along the midvein on both surfaces; apex acuminate, base obtuse to rounded; midvein sulcate adaxially and raised abaxially, secondary veins 8-14 pairs, inconspicuous adaxially and raised abaxially, marginal veins two, the inner $0.3-0.5 \mathrm{~cm}$ from the margin. Inflorescences 5-8 $\mathrm{cm}$ long, axillary or terminal; with yellowish indumentum on the rachis, sparse to dense; branching opposite or sub-opposite; bracts not seen, bracteoles not seen. Flower buds globose, ca. $0.2 \mathrm{~cm}$ long, indumentum yellow; calyx open, with 5 free lobes, these obtuse, $0.15-0.2 \mathrm{~cm}$ long. Fruits globose, $0.3-0.5 \mathrm{~cm}$ diam., not pruinose, not costate, with sparse indumentum, crowned by the calyx.

Examined material: campo nativo, estrada Paraju, 17.I.1995, D.A. Folli 2490 (CVRD); mata alta, estrada Farinha Seca, 3.I.1994, D.A. Folli 2453 (CVRD); Mussununga, estrada Mantegueira, 14.X.2004, D.A. Folli 4959 (CVRD).

Myrcia ovata is distributed from ES to SP states, in ombrophilous forests and restingas of the Atlantic domain (Santos et al. 2020). In the VNR this species has been collected in the campo nativo and in the mata alta and mussununga forests. Flowering material was collected in October and fruiting material was collected in January. It is similar to Myrcia splendens and $M$. sp.3 but differs in leaf blades with lateral veins inconspicuous adaxially ( $v s$. raised in the two latter spp.) and globose fruits (vs. ellipsoid in the two latter species).

6.4. Myrcia splendens (Sw.) DC., Prodr. 3: 244. 1828.

Figs. 3d; 8e-f

Treelets or trees $2-14 \mathrm{~m}$. Leaves with petiole $0.2-0.5 \mathrm{~cm}$ long; blade slightly discolourous, elliptic to lanceolate, $2-14 \times 1-5.5 \mathrm{~cm}$, slightly coriaceous, glabrous or with yellow to brown indumentum concentrated along the midvein on both surfaces; apex acute to acuminate, base cuneate to obtuse; midvein slightly sulcate adaxially and raised abaxially, secondary veins 6-20 pairs, raised on both surfaces, marginal veins two, the inner $0.1-0.2 \mathrm{~cm}$ from the margin. Inflorescences $3.5-11 \mathrm{~cm}$ long, axillary or terminal, with yellowish or brownish indumentum on the rachis, sparse to dense; branching opposite to sub-opposite; bracts lanceolate, $0.5-2.2 \mathrm{~cm}$ long, bracteoles lanceolate, $0.15-0.5 \mathrm{~cm}$ long. Flower buds globose, $0.15-0.25 \mathrm{~cm}$ long, indumentum yellow; calyx open, with 5 free lobes, these obtuse, $0.1-0.15 \mathrm{~cm}$ long. Fruits ellipsoid, 0.3-1.5 $\mathrm{cm}$ long, not pruinose, not costate, with sparse indumentum, crowned by the calyx. 
Examined material: capoeirão, aceiro Dois Irmãos, 24.IX.1999, D.A. Folli 3488 (CVRD); estrada Boleira, 14.IX.2004, D.A. Folli 4927 (CVRD); estrada RFL133/98, 30.IX.2004, G.S. Siqueira 115 (CVRD); mata alta, aceiro Ceolin, 21.VIII.2001, D.A. Folli 4017 (CVRD); aceiro do viveiro, 31.VIII.2012, G.S. Siqueira
773 (CVRD, RB); estrada Bicuíba, 15.IX.2004, D.A. Folli 4935 (CVRD); Mussununga, estrada Boleira, 30.X.2003, D.A. Folli 4658 (CVRD); 02.II.2017, K.S. Valdemarin \& T.B. Flores 1012 (ESA, SORO); estrada da Gávea, 23.I.1989, D.A. Folli 887 (CVRD, RB); 22.III.2019, K.S. Valdemarin et al. 1228 (ESA);

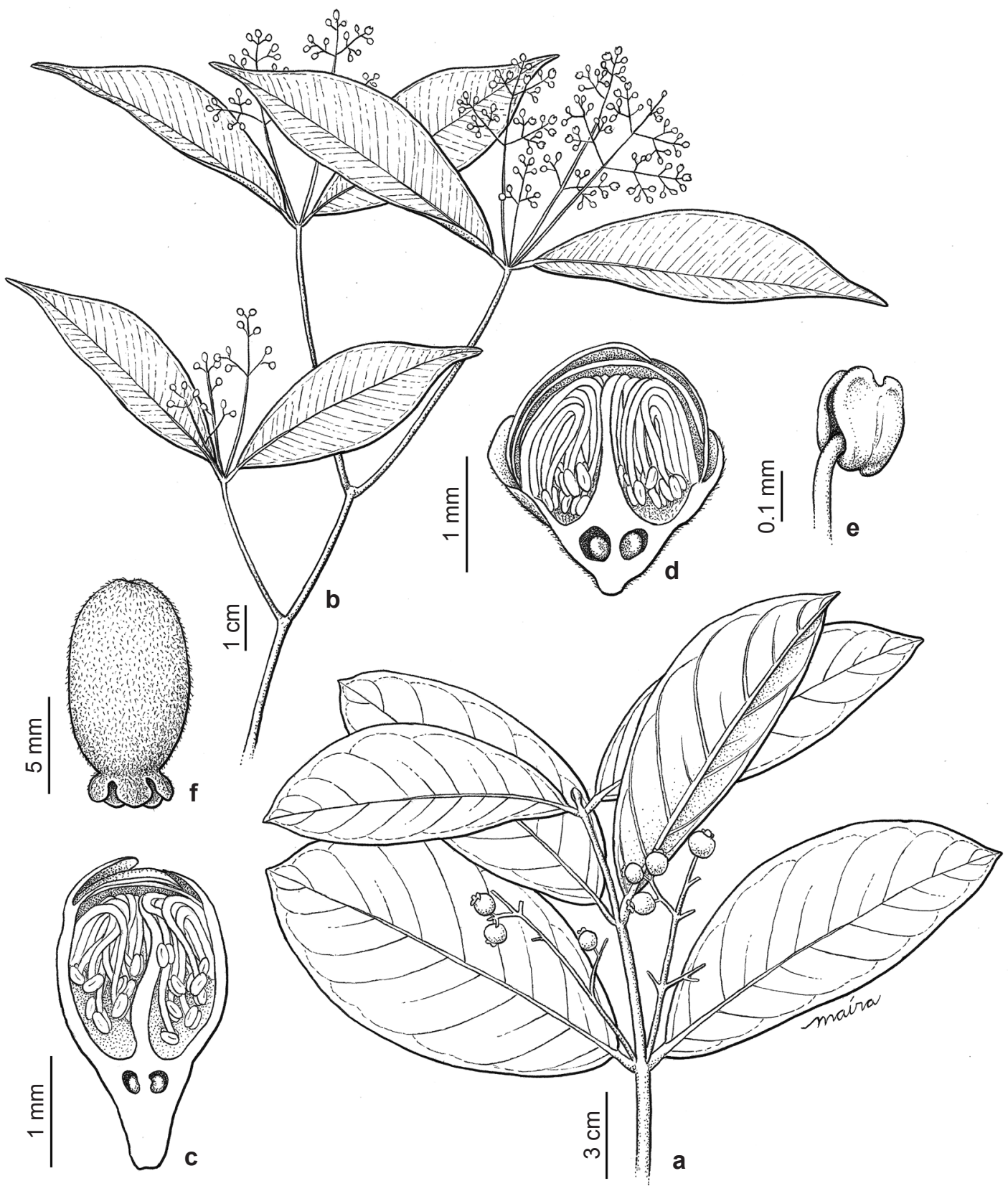

Figure 8 - a. Myrcia isaiana - branch. b-c. M. tenuifolia - b. branch; c. longitudinal section of flower bud. d. $M$. ovata - longitudinal section of flower bud. e-f. M. splendens - d. anther; e. fruit (depicted inverted). 
23.I.1989, D.A. Folli 888 (CVRD); 18.III.1996, D.A. Folli 2706 (CVRD); estrada do Flamengo, 27.XI.1989, G.L. Farias 348 (CVRD, RB); 1.III.2008, D.A. Folli 6240 (CVRD); estrada Paraju, 11.I.2007, D.A. Folli 2233 (CVRD); transição entre campo nativo e mussununga, estrada da Gávea, 26.I.2017, K.S. Valdemarin et al. 876 (ESA, SORO).

Myrcia splendens is a widespread taxon that occurs throughout Brazil, in all domains (Santos 2017; Santos et al. 2020). In the study site it was registered in the mussununga and mata alta forests, disturbed areas, and in transitional areas between the campo nativo and the mussununga forests. Flowering material was collected in January, March and from August to November and fruiting material was collected from January to March. It is a morphologically widely variable, but in the VNR it can be recognised by relatively short petioles, leaf blades acute to acuminate, and ellipsoid fruits.

\subsection{Myrcia sp.3.}

Trees 4-8 m. Leaves with petiole $0.6-0.8 \mathrm{~cm}$ long; blade concolourous, narrowly elliptic, 5-12.5 $\times 1.2-3.8 \mathrm{~cm}$, slightly coriaceous, glabrous on both surfaces or with brown indumentum abaxially; apex long-acuminate to caudate, base cuneate; midvein slightly sulcate adaxially and raised abaxially, secondary veins 10-14 pairs, flat adaxially and raised abaxially, marginal vein $0.2-0.4 \mathrm{~cm}$ from the margin. Inflorescences 4-7 cm long, axillary or terminal, with yellowish or brownish indumentum on the rachis, sparse to dense; branching opposite or sub-opposite; bracts not seen, bracteoles not seen. Flowers not seen. Fruits ellipsoid, ca. $1.5 \mathrm{~cm}$ long, not pruinose, not costate, with sparse indumentum, crowned by the calyx.

Examined material: mata alta, estrada municipal Canto Grande, 14.III.2007, D.A. Folli 5515 (CVRD); Mussununga, estrada da Gávea, 11.III.2009, D.A. Folli 6309 (CVRD).
Myrcia sp.3 has been collected in the mata alta and mussununga forests of the study site with fruits in March. It can be recognized by narrowly elliptic, long-acuminate to caudate leaf blades ellipsoid fruits. It resembles Mycia splendens; for distinction between them see the identification key.

7. Myrcia sect. Reticulosae D.F.Lima \& E.Lucas, Kew Bull. 73(9): 8. 2018.

Vegetative branching monopodial. Leaves with inter-secondary and tertiary veins raised, conspicuously reticulate; blade not strongly discolourous, abaxial surface not visibly contrasting with dark dots. Inflorescences with opposite branching. Flower buds obovoid; calyx free in bud, opening in 5 intact lobes; hypanthium longitudinally prolonged above the summit of the ovary, glabrous on the inner surface; flower disc glabrous, staminal ring pubescent (exceptionally glabrous in $M$. maximiliana), comprising at least $60 \%$ of the total disc width; anthers with symmetrical thecae, reversing curvature at dehiscence; ovary 3-locular, with two ovules per locule. Fruits ellipsoid, crowned by the hypanthial tube and the calyx.

Two species of Myrcia sect. Reticulosae occur in the VNR, a group of ca. 20 taxa distributed in the Cerrado and Atlantic domains (Lucas et al. 2018). This section is characterised by flowers with extended hypanthium, glabrous floral disc, pubescent and thick staminal ring, and 3-locular ovary (Salgueirinho 2020). However, this work follows Lucas et al. (2018) in accepting Myrcia maximiliana, a species of flowers with glabrous staminal ring, in $M$. sect. Reticulosae. A phylogenetic study of Amorim et al. (2019) showed the emergence of that species in a morphologically cohesive clade that may be described as a new section in the future.

\section{Key to species of Myrcia sect. Reticulosae in the VNR}

1. Trees ca. $16 \mathrm{~m}$; leaf blades elliptic, 4.5-11 $\times 2-6.2 \mathrm{~cm}$, chartaceous, indumentum dense abaxially, marginal veins two 7.1. Myrcia felisbertii

1'. Shrubs or trees 2-5 m; leaf blades oblong, 8.5-19.8 $\times 5-7.9 \mathrm{~cm}$, coriaceous, indumentum sparse abaxially, marginal vein single. 7.2. Myrcia maximiliana

7.1. Myrcia felisbertii (DC.) O.Berg, Fl. bras. 14: 562. 1859.

Trees ca. $16 \mathrm{~m}$. Leaves with petiole $0.6-0.8$ $\mathrm{cm}$ long; blade discolourous, elliptic, 4.5-11 $\times$
2-6.2 cm, chartaceous, with sparse, yellow to brown indumentum on both surfaces; apex acute to short-acuminate, base cuneate to obtuse; midvein sulcate adaxially and raised abaxially, secondary 
veins $14-18$ pairs, raised on both surfaces, marginal veins two, the inner $0.15-0.20 \mathrm{~cm}$ from the margin. Inflorescences $2-4.3 \mathrm{~cm}$ long, axillary or terminal, with yellowish to brownish indumentum on the rachis; branching opposite; bracts not seen; bracteoles not seen. Flower buds obovoid, ca. $0.5 \mathrm{~cm}$ long, indumentum yellow to brown; calyx open, with 5 free lobes, these acute obtuse, ca. $0.2 \mathrm{~cm}$ long. Fruits ellipsoid, 1.7-2.1 $\mathrm{cm}$ long, not pruinose, slightly costate or not, indumentum present, crowned by the hypanthial tube and the calyx.

Examined material: mata alta, estrada Boleira, 15.XII.1980, I.A. Silva 227 (CVRD, RB, RBR).

Additional material: BRAZIL. BAHIA: Ilhéus, rodovia Ilhéus Itacaré (BA-001), km 20, 19.II.2005, $P$. Fiaschi et al. 2707 (SPF).

Myrcia felisbertii is endemic to the Atlantic domain, occurring in the ombrophilous forests from PE to ES states (Santos et al. 2020). In the VNR it was collected in the mata alta forests with flowers in December and fruits in April. This species is distinguished from Myrcia maximiliana by leaf features (see the identification key), flowers not of little aggregated in inflorescences (vs. strongly aggregated in the latter), and flower buds ca. $0.5 \mathrm{~cm}$ long (vs. ca. $0.3 \mathrm{~cm}$ in the latter).

7.2. Myrcia maximiliana O.Berg, Linnaea 27: 89. 1855.

Shrubs or trees 2-5 m. Leaves with petiole $0.7-1.3 \mathrm{~cm}$ long; blade slightly discolourous, oblong, 8.5-19.8 × 5-7.9 cm, coriaceous, glabrous or with sparse, yellow indumentum concentrated along the midvein and the secondary veins adaxially and with dense, yellow to brown indumentum abaxially; apex acute to acuminate, rarely obtuse, base obtuse; midvein sulcate adaxially and raised abaxially, secondary veins 12-20 pairs, raised on both surfaces, marginal vein ca. $0.5 \mathrm{~cm}$ from the margin. Inflorescences $2-5.4 \mathrm{~cm}$ long, terminal, with yellowish to brownish indumentum on the rachis, dense; branching opposite; bracts lanceolate, ca. 1 $\mathrm{cm}$ long. bracteoles lanceolate, ca. $0.7 \mathrm{~cm}$ long. Flower buds obovoid, ca. $0.3 \mathrm{~cm}$ long, indumentum yellow to brown, dense; calyx open, with 5 free lobes, these lanceolate, $0.8-1 \mathrm{~cm}$ long. Fruits ellipsoid, ca. $1.1 \mathrm{~cm}$ long, not pruinose, not costate, with indumentum, crowned by the hypanthial tube and the calyx.
Examined material: mata alta, estrada do Flamengo, 12.XII.2012, G.S. Siqueira 841 (CVRD, RB); mata ciliar, estrada do Flamengo, 22.X.2004, D.A. Folli 4966 (CVRD, RB, SPF).

Additional material: BRAZIL. ESPÍRITO SANTO: Conceição da Barra, Flona do Rio Preto, trilha do Canastra, 21.II.2019, R. Nichio-Amaral et al. 611 (VIES).

Myrcia maximiliana can be found in BA and ES states, in the Atlantic domain (Santos et al. 2020). Within the study site it can be found in the mata alta forests and riverside areas. Flowering material was collected in October and December. This species can be recognised by corymbiform inflorescences (with short lateral branches clustered at the apex of the rachis) and flowers with thick, glabrous staminal ring.

\section{Myrcia sect. Sympodiomyrcia M.F.Santos \&} E.Lucas, Taxon 65(4): 768. 2016.

Vegetative branching sympodial. Leaves with inter-secondary and tertiary veins usually flat; blade not strongly discolourous, abaxial surface not visibly contrasting with dark dots. Inflorescences with opposite branching. Flower buds obovoid or turbinate; calyx free in bud, opening in 5 partly torn lobes transversely; hypanthium longitudinally prolonged above the summit of the ovary, glabrous on the inner surface; flower disc glabrous, staminal ring glabrous, comprising up to $40 \%$ of the total disc width; anthers with symmetrical thecae, reversing curvature on dehiscence; ovary 2-locular, with two ovules per locule. Fruits globose, crowned by by the hypanthial tube and remnants of the calyx.

Myrcia sect. Sympodiomyrcia has 22 species (Santos et al. 2018; Fernandes et al. 2019), a section with disjoint distribution between the Guiana Shield and the Cerrado and Atlantic domains (Santos et al. 2016). The three species of this section that occur in the study site are characterised by sympodial vegetative branching, inflorescences with opposite branching, flower disc glabrous, and hypanthium extended beyond the 2-locular ovaries. A distinctive feature of this section is transversal tearing of calyx lobes (i.e., parallel to the hypanthium rim) at anthesis (Lucas et al. 2018), occasionally completely detaching and falling apart from the flower. More than one inflorescence per axil is also frequent in species Myrcia sect. Sympodiomyrcia. 


\section{Key to species of Myrcia sect. Sympodiomyrcia in the VNR}

1. Inflorescence rachis with ferruginous indumentum; leaf blades oblong to oblanceolate, apex acute to short-acuminate 8.1. Myrcia plusiantha

1'. Inflorescence rachis with yellowish-brown indumentum; leaf blades elliptic to obovate, apex acuminate to long-acuminate. 8.2. Myrcia tenuifolia

8.1. Myrcia plusiantha Kiaersk., Enum. Myrt. Bras. 66. 1893.

Myrcia follii G.M.Barroso \& Peixoto, Acta Bot. Bras. 4(2): 4. 1990.

Trees 4-15 m. Leaves with petiole $0.6-1.5 \mathrm{~cm}$ long; blade discolourous, oblong to oblanceolate, $18-23.5 \times 7-10 \mathrm{~cm}$, chartaceous, glabrous adaxially and with sparse, ferruginous indumentum abaxially; apex acute to short-acuminate, base cuneate to obtuse; midvein sulcate adaxially and raised abaxially, secondary veins $18-20$ pairs, inconspicuous adaxially and raised abaxially, marginal veins two, the inner $0.3-0.5 \mathrm{~cm}$ from the margin. Inflorescences $4.5-11.2 \mathrm{~cm}$ long, terminal, with ferruginous indumentum on the rachis, sparse to dense; branching opposite; bracts not seen, bracteoles not seen. Flower buds obovoid, 0.2-0.3 $\mathrm{cm}$ long, indumentum dense, ferruginous; calyx open, with 5 free lobes, these obtuse to rounded, ca. $0.05-0.1 \mathrm{~cm}$ long. Fruits globose, $0.7-1.2 \mathrm{~cm}$ diam., not pruinose, not costate, glabrous or with sparse indumentum, crowned by the hypanthial tube and the calyx.

Examined material: mata alta, estrada Farinha Seca, 23.XI.1988, D.A. Folli 821 (CVRD, RB); 8.III.1989, G.L. Farias 255 (CVRD, RB); 14.IV.2005, D.A. Folli 5048 (CVRD); mata ciliar, estrada Louro, 2.IV.2007, D.A. Folli 5540 (CVRD).

Myrcia plusiantha can be found from BA to SC states, in ombrophilous forests of the Atlantic domain (Santos et al. 2020). In the study site it was collected in the mata alta forests riparian vegetation; flowers were collected in November and fruits were collected in March and April. It is distinguished from Myrcia tenuifolia in the VNR by oblong to oblanceolate leaves with acute or short-acuminate apex and ferruginous indumentum covering the abaxial surface of the leaves, inflorescences, and flower buds. The name Myrcia folli, published with basis on specimens collected in the VNR, is a synonym of M. plusiantha (Santos et al. 2020).

8.2. Myrcia tenuifolia (O.Berg) Sobral, Novon 16: 136. 2006.

Figs. 8b-c; 9c

Trees 13-19 m. Leaves with petiole $0.4-1$ $\mathrm{cm}$ long; blade slightly discolourous, elliptic to obovate, $3-10 \times 1.5-4.3 \mathrm{~cm}$, chartaceous, glabrous or with sparse, dark indumentum on both surfaces; apex acuminate to caudate, base obtuse, cuneate, or attenuate; midvein sulcate adaxially and raised abaxially, secondary veins 8-20 pairs, inconspicuous adaxially and flat to raised abaxially, marginal veins two, the inner $0.05-0.10 \mathrm{~cm}$ from the margin. Inflorescences $2-9.5 \mathrm{~cm}$ long, axillary or terminal, with yellowish-brown indumentum on the rachis sparse; branching opposite; bracts not seen, bracteoles lanceolate, ca. $0.1 \mathrm{~cm}$ long. Flower buds turbinate, $0.25-0.3 \mathrm{~cm}$ long, glabrous; calyx open, with 5 free lobes, these obtuse to rounded, ca. $0.05-0.1 \mathrm{~cm}$ long. Fruits globose, $0.4-1 \mathrm{~cm}$ diam., not pruinose, not costate, glabrous, crowned by the hypanthial tube and the calyx.

Examined material: mata alta, estrada Farinha Seca, 26.X.1982, I.A. Silva 357 (CVRD, RBR); 25.IV.1983, D.A. Folli 443 (CVRD, RB, RBR); estrada Jueirana Vermelha, 3.VI.2004, D.A. Folli 4863 (CVRD); 10.VI.2014, D.A. Folli 7223 (CVRD, RB); estrada municipal Canto Grande, 17.XI.2011, M.F. Santos et al. 747 (RB); mata ciliar, estrada municipal Canto Grande, 17.III.2004, D.A. Folli 4768 (CVRD); 17.XI.2011, D.A. Folli 6805 (CVRD, RB).

Myrcia tenuifolia occurs in BA and ES states, in the Atlantic domain (Santos et al. 2020). In the study site it was collected in the mata alta forests and riparian vegetation, where flowers were found in October and November and fruits were found in March, April, and June. This species is characterised in the study site by sympodial inflorescences with many axes arising on the same axil and sparse indumentum on leaf blades and inflorescences.

Species of uncertain infra-generic position

Myrcia sp.4.

Fig. 9f

Trees ca. $18 \mathrm{~m}$. Leaves with petiole $0.8-1.5$ $\mathrm{cm}$ long; blade slightly discolourous, ovate or oblong, 5.2-10 × 1.3-3.4 cm, chartaceous, glabrous on both surfaces; apex long-acuminate or caudate, base obtuse and decurrent on the petiole; midvein sulcate adaxially and raised abaxially, secondary veins 15-20 pairs, inconspicuous on both surfaces, 


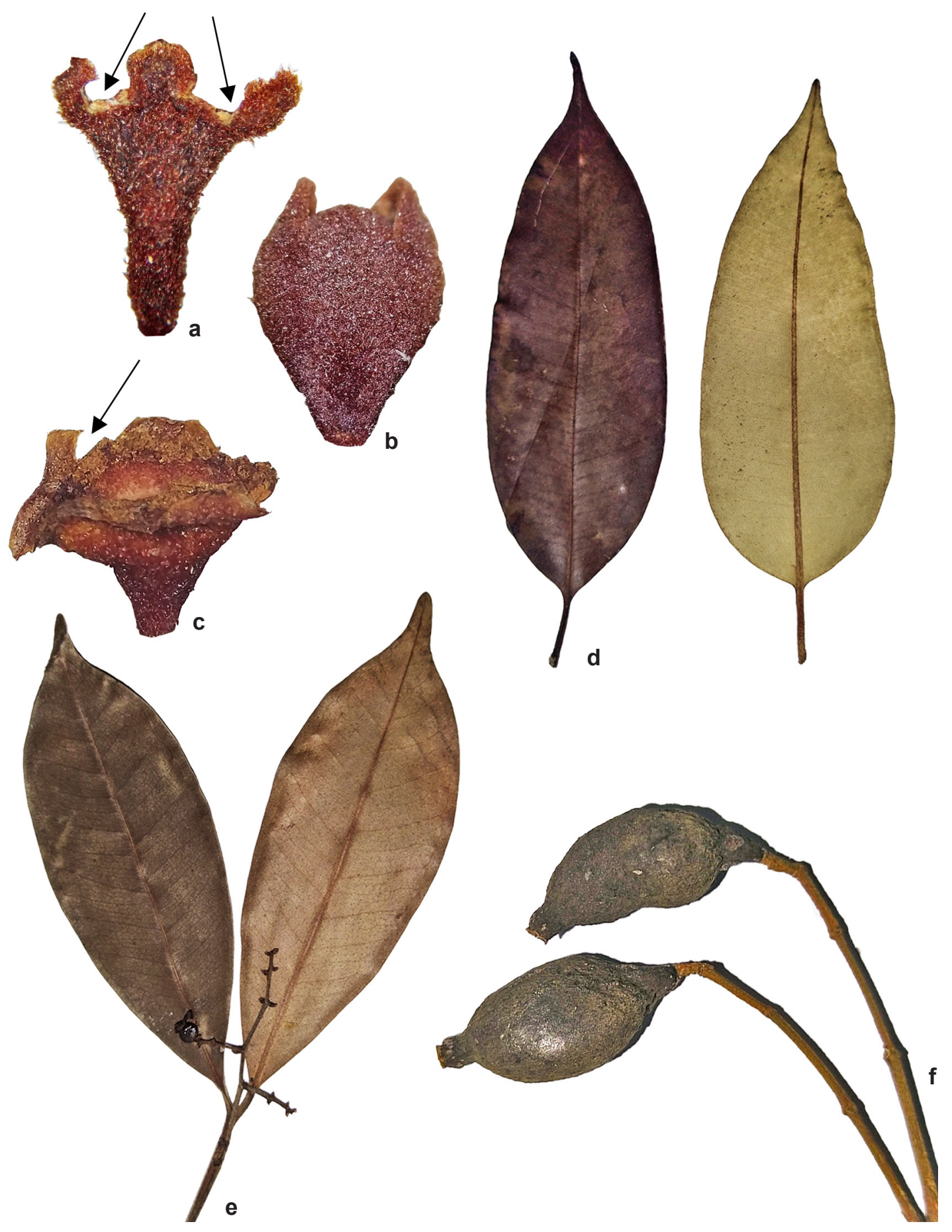

Figure 9-a, d. Myrcia polygama - a. old flower, arrows indicating partly torn calyx lobes; d. leaves. b. M. ferruginosa - flower bud. c. M. tenuifolia - old flower, arrow indicating partly torn calyx lobe. e. M. excoriata - branchlet. f. Myrcia sp.4 - fruits. Scale bars are omitted as the images depict characters only. 
marginal vein ca. $0.05 \mathrm{~cm}$ from the margin. Inflorescences $6.2-10.3 \mathrm{~cm}$, terminal, glabrous; branching opposite; bracts not seen, bracteoles not seen. Flower buds not seen. Fruits fusiform, 2.7-3 $\times 0.9-1.4 \mathrm{~cm}$, not pruinose, not costate, glabrous, crowned by the hypanthial tube.

Examined material: Mussununga, estrada Orelha de Onça, 9.I.1995, D.A. Folli 2462 (CVRD, SORO).

Myrcia sp.4 is known by a single gathering made within the VNR. Fruits were collected in January. This species resembles Myrcia polygama in its long-petiolated leaves with long, narrow blade apex, but differs by sympodial vegetative branching (vs. monopodial in M. polygama) and fusiform fruits 2.7-3 cm long (vs. globose, ca. $1 \mathrm{~cm}$ diam. in M. polygama). Myrcia sp.4 might be assigned to Myrcia sect. Eugeniopsis with basis on strong resemblance with Myrcia polygama, but it does not have the markedly discolourous leaves usual of taxa of that section. Sympodial vegetative branching suggests affinity with Myrcia sect. Calyptranthes or $M$. sect. Sympodiomyrcia, however, the lack of calyx remnants in the examined material makes such a placement unfeasible.

\section{Discussion}

The VNR is crucial for conservation of Myrcia in Espírito Santo because it not only houses virtually half of the species of the genus that occur in the whole state, but also belongs to a mosaic of natural protected areas immersed in an essentially agricultural landscape (SOS Mata Atlântica \& INPE 2020). In addition, Myrtaceae is considered a model-taxon in the Atlantic domain (Lucas \& Bünger 2015); hence, the data here presented, including the record of a series of endemic and threatened species, corroborates that the VNR must be considered a major site for biodiversity conservation.

Giaretta et al. (2016) provided a list containing 44 species of Myrciinae registered in the VNR, a number increased in two by this study. However, data of species composition furnished by these authors considerably differ from that of the results here revealed: the occurrences of Myrcia bicolor Kiaersk., M. eugenioides Cambess., M. guianensis (Aubl.) DC., M. multipunctata Mazine, M. neoglabra E.Lucas \& C.E.Wilson, M. pubipetala Miq., and M. tenuivenosa Kiaersk. could not be confirmed. On the other hand, eight species are novel records in the study site: Myrcia congestiflora, M. cymatophylla, M. felisbertii, $M$. gaudichaudiana, $M$. insularis, $M$. laxiflora, $M$. pteropoda, and M. scytophylla. Such an update in species composition stresses the importance of local flora surveys in the refinement of botanical knowledge.

Six currently accepted species of Myrcia have been described from material collected in the VNR in recent decades: Myrcia excelsa, $M$. gilsoniana, $M$. isaiana, $M$. riodocensis, $M$. stellaris, and $M$. sucrei (Barroso \& Peixoto 1990; Gaem et al. 2021a, 2021b). This number reflects the research policy traditionally adopted by the conservation site, which is fundamental due to its singular natural attributes.

\section{Acknowledgements}

To the Vale Natural Reserve team and Thiago Flores, for support during investigation. To the Sooretama Biological Reserve, for providing accommodation during the field surveys. To the cited herbaria and their respective curators, for granting access to collections. To the following myrtologists, for precious discussions: Augusto Giaretta, Duane Fernandes Lima, Marcos Sobral, Matheus Fortes Santos, and Thiago Fernandes. KSV thanks The Explorers Club, for the Mamont Scholar Grant to carry out field activities. This study was financed in part by the Coordenação de Aperfeiçoamento de Pessoal de Nível Superior - Brasil (CAPES) - Finance Code 001 and Conselho Nacional de Desenvolvimento Científico e Tecnológico (CNPq) - research grant 302309/2018-7.

\section{References}

Amorim BS (2017) Filogenia e estudos taxonômicos no clado Gomidesia (Myrtaceae, Myrcia s.l.) na floresta atlântica do Brasil. PhD. Thesis. Universidade Federal de Pernambuco, Recife. 190p.

Amorim BS, Vasconcelos TNC, Souza G, Alves M, Antonelli A \& Lucas E (2019) Advanced understanding of phylogenetic relationships, morphological evolution and biogeographical history of the mega-diverse plant genus Myrcia and its relatives (Myrtaceae: Myrteae). Molecular Phylogenetics and Evolution 138: 65-88.

Araújo DSD, Pereira OJ \& Peixoto AL (2008) Campos Nativos at the Linhares Forest Reserve, Espírito Santo, Brazil. In: Thomas WW (ed.) The Atlantic Coastal Forest of Northeastern Brazil. The New York Botanical Garden Press, New York. Pp. 371-185.

Barroso GM \& Peixoto AL (1990) Espécies novas de Myrcia DC. e Marlierea Cambes. (Myrtaceae). Acta Botanica Brasilica 4: 3-19.

Barroso GM \& Peixoto AL (1995) Myrtaceae da Reserva Florestal de Linhares, Espírito Santo, Brasil - Gêneros 
Calyptranthes e Marlierea. Boletim do Museu de Biologia Mello Leitão 3: 3-38.

CNCFlora (2020) Lista vermelha da flora brasileira versão 2012.2. Centro Nacional de Conservação da Flora. Available at $<$ http://cncflora.jbrj.gov.br/portal/>. Access on 20 November 2020.

Engel VL \& Martins FR (2005) Reproductive phenology of Atlantic forest tree species in Brazil: an eleven year study. Tropical Ecology 46: 1-16.

Fernandes T, Sobral M, Santos MF \& Braga JMA (2019) Myrcia auriculata (Myrtaceae), a new species from the Brazilian Atlantic Forest. Phytotaxa 399: 77-82.

Gaem PH, Fernandes T, Valdemarin KS, Lucas E \& Mazine FF (2021a) Myrcia excelsa (Myrtaceae), a new species from Espírito Santo, Brazil. Phytotaxa 501: 293-296.

Gaem PH, Scaravelli FS, Valdemarin KS, Lucas E \& Mazine FF (2021b) Star myrtle, a new Myrcia (Myrtaceae) from Espírito Santo, Brazil. Brittonia 73: 304-310.

Giaretta A \& Peixoto AL (2015) Myrtaceae da restinga do norte do Espírito Santo, Brasil. Boletim do Museu de Biologia Mello Leitão 37: 53-134.

Giaretta A, Menezes LTF \& Peixoto AL (2015) Diversity of Myrtaceae in the southeastern Atlantic forest of Brazil as a tool for conservation. Brazilian Journal of Botany 38: 175-185.

Giaretta A, Tuler AC, Souza MC, Valdemarin KS, Mazine FF \& Peixoto AL (2016) Diversidade de Myrtaceae na Reserva Natural Vale. In: Rolim SG, Menezes LTF \& Srbek-Araujo AC (eds.) Floresta Atlântica de Tabuleiro: diversidade e endemismos na Reserva Natural Vale. Editora Rona, Belo Horizonte. Pp. 21-30.

IBGE - Instituto Brasileiro de Geografia e Estatística (2020) Cidades e Estados. Available at $<$ https://www.ibge. gov.br/>. Access on 20 June 2020.

Jesus RM \& Rolim SG (2005) Fitossociologia da Mata Atlântica de Tabuleiro. Boletim Técnico da Sociedade de Investigações Florestais 19: 1-149.

Jesus RM, Souza AL \& Garcia A (1992) Produção sustentável de floresta atlântica. Sociedade de Investigações Florestais, Viçosa.

Lima DF, Goldenberg R, Forest F, Cowan RS \& Lucas E (2021) Phylogeny and biogeography of Myrcia sect. Aguava (Myrtaceae, Myrteae) based on phylogenomic and Sanger data provide evidence for a Cerrado origin and geographically structured clades. Molecular Phylogenetics and Evolution 157: 107043.

Lourenço AR, Burton GP, Alves M \& Lucas E (2020) Myrcia sect. Calyptranthes (Myrtaceae) from the Atlantic Forest, Brazil. Phytotaxa 460: 12-58.

Luber J, Oliveira MIU, Ferreira MFS \& Carrijo TT (2017) Flora do Espírito Santo: Campomanesia (Myrtaceae). Rodriguésia 68: 1767-1790.

Lucas EJ \& Bünger MO (2015) Myrtaceae in the Atlantic Forest: their role as "model" group. Biodiversity and Conservation 24: 2165-2180.

Lucas EJ, Matsumoto K, Harris SA, Nic Lughadha EM, Benardini B \& Chase MW (2011) Phylogenetics, morphology, and evolution of the large genus Myrcia s.l. (Myrtaceae). International Journal of Plant Sciences 172: 915-934.

Lucas EJ, Wilson CE, Lima DF, Sobral M \& Matsumoto K (2016) A conspectus of Myrcia sect. Aulomyrcia (Myrtaceae). Annals of the Missouri Botanical Garden 101: 648-698.

Lucas EJ, Amorim BS, Lima DF, Lima-Lourenço AR, Nic Lughadha EM, Proença CEB, Rosa PO, Rosário AS, Santos LL, Santos MF, Souza MC, Staggemeier VG, Vasconcelos TNC \& Sobral M (2018) A new infrageneric classification of the species-rich Neotropical genus Myrcia s.l. Kew Bulletin 73: 9.

Lucas EJ, Holst B, Sobral M, Mazine FF, Nic Lughadha EM, Proença CEB, Costa IR \& Vasconcelos TNC (2019) A new subtribal classification of tribe Myrteae (Myrtaceae). Systematic Botany 44: 560-569.

Mazine FF \& Souza VC (2007) Myrtaceae nos campos de altitude do Parque Nacional do Caparaó - Espírito Santo / Minas Gerais, Brasil. Rodriguésia 59: 57-74.

Mazine FF \& Souza VC (2009) New species of Eugenia sect. Racemosae (Myrtaceae) from the Atlantic Forest, Eastern Brazil. Novon 19: 80-84.

Oliveira-Filho AT \& Fontes MAL (2000) Patterns of floristic differentiation among Atlantic Forests in Southeastern Brazil and the influence of climate. Biotropica 32: 793-810.

Peixoto AL \& Silva IM (1997) Tabuleiro forests of Northern Espirito Santo, South-eastern Brazil. In: Davis SD, Heywood VH, Herrera-Macbride O \& Hamilton AC (eds.) Centres of plant diversity: a guide strategy for their conservation. IUCN Publications, Cambridge. Pp. 369-372.

Peixoto AL \& Jesus RM (2016) Reserva Natural Vale: memórias de 65 anos de conservação. In: Rolim SG, Menezes LTF \& Srbek-Araujo AC (eds.) Floresta Atlântica de Tabuleiro: diversidade e endemismos na Reserva Natural Vale. Editora Rona, Belo Horizonte. Pp. 21-30.

Peixoto AL, Silva IM, Pereira OJ, Simonelli M, Jesus RM \& Rolim SG (2008) Tabuleiro Forests North of the Rio Doce: their representation in the Vale do Rio Doce Natural Reserve, Espírito Santo, Brazil. Memoirs of the New York Botanical Garden 100: 319-350.

Rolim SG, Peixoto AL, Pereira OJ, Araújo DSD, Nadruz M, Siqueira G \& Menezes LTF (2016a) Angiospermas da Reserva Natural Vale, na Floresta Atlântica do norte do Espírito Santo. In: Rolim SG, Menezes LTF \& SrbekAraujo AC (eds.) Floresta Atlântica de Tabuleiro: diversidade e endemismos na Reserva Natural Vale. Editora Rona, Belo Horizonte. Pp. 167-230.

Rolim SG, Ivanauskas NM \& Engel VL (2016b) As florestas de tabuleiro do norte do Espírito Santo são ombrófilas ou estacionais? In: Rolim SG, Menezes LTF \& Srbek-Araujo AC (eds.) Floresta Atlântica de Tabuleiro: diversidade e endemismos na Reserva Natural Vale. Editora Rona, Belo Horizonte. Pp. 47-60. 
Salgueirinho TFS (2020) Revisão taxonômica de Myrcia sect. Reticulosae (Myrtaceae). MS Thesis. Instituto de Pesquisas do Jardim Botânico do Rio de Janeiro, Rio de Janeiro. 212p.

Santos LL (2017) Taxonomia e filogenia de Myrcia sect. Myrcia (Myrcia s.l., Myrtaceae). PhD Thesis. Universidade Federal Rural de Pernambuco, Recife. 319 p.

Santos MF \& Fernandes T (2020) Myrcia suberosa: a new species of Myrcia sect. Eugeniopsis (Myrciinae, Myrteae, Myrtaceae) endemic to the Atlantic Forest. Phytotaxa 450: 95-101.

Santos MF, Santo PT, Forest F \& Lucas E (2016) Phylogeny, morphology and circumscription of Myrcia sect. Sympodiomyrcia (Myrcia s.l., Myrtaceae). Taxon 65: 759-774.

Santos MF, Lucas E, Sano PT, Buerki S, Staggemeier VG \& Forest F (2017) Biogeographical patterns of Myrcia s.l. (Myrtaceae) and their correlation with geological and climatic history in the Neotropics. Molecular Phylogenetics and Evolution 108: 34-48.

Santos MF, Lucas E \& Sano PT (2018) A taxonomic monograph of Myrcia sect. Sympodiomyrcia (Myrteae, Myrtaceae). Phytotaxa 380: 1-114.

Santos MF, Santo PT \& Lucas E (2019) Taxonomic updates in South American Myrcia (Myrtaceae: Myrteae): lectotypes, synonyms, new combinations and new names in Myrcia sect. Eugeniopsis. Kew Bulletin 74: 58.

Santos MF, Amorim BS, Burton GP, Fernandes T, Gaem PH, Lourenço ARL, Lima DF, Rosa PO, Santos LLD, Staggemeier VG, Vasconcelos TNC \& Lucas EJ (2020) Myrcia. In: Flora do Brasil 2020. Instituto de Pesquisas Jardim Botânico do Rio de Janeiro. Available at $<\mathrm{http}$ ://floradobrasil.jbrj.gov.br/reflora/ floradobrasil/FB10660>. Access on 22 November 2020.

Schmid R (1972) A resolution of the Eugenia-Syzygium controversy (Myrtaceae). Americal Journal of Botany 59: 423-436.

Simonelli M, Souza AL, Peixoto AL \& Silva AF (2008) Floristic composition and structure of the tree component of a Muçununga Forest in the Linhares Forest Reserve, Espírito Santo, Brazil. Memoirs of the New York Botanical Gardarden 100: 345-364.

Sobral M (2007) Evolução do conhecimento taxonômico do Brasil (1990-2006) e um estudo de caso: a família Myrtaceae no município de Santa Teresa, Espírito Santo. PhD Thesis. Universidade Federal de Minas Gerais, Belo Horizonte. 360p.

SOS Mata Atlântica \& INPE (2020) Fundação SOS
Mata Atlântica \& Instituto Nacional de Pesquisas Espaciais. Atlas dos Remanescentes Florestais da Mata Atlântica: período 2018-2019: relatório técnico. Available at $<\mathrm{http}$ ://mapas.sosma.org.br/site_media/ download/2020_Atlas_Mata_Atlantica_2018-2019_ relatorio_tecnico_final.pdf $>$. Access on 15 May 2021.

Thiers B [continuously updated] Index Herbariorum: a global directory of public herbaria and associated staff. New York Botanical Garden's Virtual Herbarium. Available at $<$ http://sweetgum.nybg.org/ science/ih/>. Access on 22 November 2020.

Tuler AC, Carrijo TT, Ferreira MFS \& Peixoto AL (2017) Flora of Espírito Santo: Psidium (Myrtaceae). Rodriguésia 68: 1791-1805.

Turland NJ, Wiersema JH, Barrie FR, Greuter W, Hawksworth DL, Herendeen PS, Knapp S, Kusber W-H, Li D-Z, Marhold K, May TW, McNeill J, Monro AM, Prado J, Price MJ \& Smith GF (2018) International code of nomenclature for algae, fungi, and plants (Shenzhen Code) adopted by the Nineteenth International Botanical Congress Shenzhen, China, July 2017. Regnum Vegetabile 159. Koeltz Botanical Books, Glashütten. Available at $<$ https://www.iapt-taxon.org/nomen/main.php $>$. Access on 10 May 2021.

Valdemarin KS, Mazine FF \& Souza VC (2019a) Eugenia ochracea (Myrtaceae, Myrteae), a new species from Atlantic forest of Espírito Santo, Brazil. Brittonia 71: 318-324.

Valdemarin KS, Giaretta A, Sobral M, Souza VC \& Mazine FF (2019b) Two new species of Eugenia (Myrtaceae, Myrteae) with fused calyx from the Atlantic coastal forest, Brazil. Phytotaxa 403: 99-110.

Valdemarin KS, Faria JEQ, Mazine FF \& Souza VC (2020a) A new species of Eugenia subg. Pseudeugenia (Myrtaceae, Myrteae) from Brazilian Atlantic Forest. Systematic Botany 45: 537-543.

Valdemarin KS, Souza VC \& Mazine FF (2020b) Two new and threatened Eugenia (Myrtaceae) species from the Atlantic Forest of Espírito Santo, Brazil. Phytotaxa 468: 203-213.

Vasconcelos TNC, Prenner G, Santos MF, Wingler A \& Lucas EJ (2017) Links between parallel evolution and systematic complexity in angiosperms - a case study of floral development in Myrcia s.l. (Myrtaceae). Perspectives in Plant Ecology, Evolution and Systematics 24: 11-24.

Wilson PG, O'Brien MM, Heslewood MM \& Quinn CJ (2001) Myrtaceae revisited: a reassessment of infrafamilial groups. American Journal of Botany 88: 2013-2025. 